\title{
CONTRIBUTIONS TO THE HYDROLOGY OF THE UNITED STATES, 1915.
}

Nathan C. Grover, Chief Hydraulic Engineer.

\section{GROUND WATER FOR IRRIGATION IN THE SACRAMENTO VALLEY, CALIFORNIA.}

By KirK Bryan.

\section{INTRODUCTION.}

No phase of the history of California is more striking and interesting than the economic and social changes which are now affecting the Sacramento Valley. These changes cover the whole field of human activity, and yet in a peculiar sense the control and use of water are the vital factors which differentiate the development of this valley from the industrial expansion that has been common to the whole country since the Civil War. Each step in the mastery of water adds impetus to the basic industry of agriculture and, through the ramifications of industry and trade, brings progressive changes to all parts of the social fabric.

The control of rivers for navigation and flood protection, the drainage of swamp lands, the harnessing of mountain streams for the production of electric power, and the use of both surface and underground water for irrigation and domestic purposes present problems which "involve in so complete and fascinating a way all of the phases of hydraulic engineering." 1 The solution of these problems is being accomplished with amazing rapidity, largely by private interests, working under wise laws and effective supervision and control by State and Federal bodies.

The possibilities of the Sacramento Valley were early appreciated by the Spanish colonists of California, but the vastness of the province, its distance from Mexico, and the intractability of the northern Indians prevented them from making settlements north of Sonoma. American immigrants, beginning with Gordon, Knight, Wolfskill, and Sutter, recognized the value of the country for raising cattle and established ranches on lands granted by the Mexican Government.

1 Mendenhall, W. C., Preliminary report on the ground waters of San Joaquin Valley, Cal.: U. S. Geol. Survey Water-Supply Paper 222, p. 49, 1908. 
The valley was the stronghold of the Americans during the conquest in 1845, and many of the settlers became rich in the mines in the years following the discovery of gold in 1848. The commercial production of wheat in this area was begun by Gen. John Sutter in $1843,{ }^{1}$ and until very recently the growing of wheat and barley by dryfarming methods has been the principal agricultural industry.

The use of water for irrigation has developed slowly and has encountered a curious apathy, in contrast to the enthusiasm for reclamation by drainage. Because of a mild climate, a concentrated winter rainfall, and a shallow water table, many field crops and deep-rooted plants thrive without irrigation. Water is not a necessity; it only makes possible larger yields, the cultivation of crops with a higher return to the acre, and the cultivation of certain lands otherwise chiefly valuable for grazing. Such advantages have had little weight with owners of large holdings to whom the original cost of the land was small. However, the crowding in of home seekers from the East, the diminishing profits of grain farming, and the increase in land values have combined to bring about the subdivision and sale of many large parcels of land. To the purchasers of such tracts the advantages of irrigation appeal more strongly.

The price of land is based on its anticipated value under irrigation and not on its value for dry farming. When subdivided, it is sold for two to three times its value for grain raising, and for many tracts the purchaser must provide the means of irrigation. The colonizing of subdivided lands has become a business and is in the main conducted by reputable firms. A large block of land is purchased and surveyed into small tracts with provision for roads and perhaps for a town site. Irrigation works may be provided or a demonstration well and pumping plant installed with the intention that the settlers should install private plants, using wells for obtaining water. Purchasers are attracted by agents and advertising. Charges of fraud have been made and doubtless in some cases are justified, but wide publicity and cooperation among real estate men are eliminating false and exaggerated statements. Intending settlers should exercise caution, view the property, compare it with similar offers, and be sure that they are getting good land well situated for a fair price. The value of farm land rests primarily on the quality of the soil and the value of the crops which it will produce, but the price of similar land varies' with proximity to market, towns, and schools, with danger of floods and assessments for reclamation, with the kind of irrigation feasible, and with many other local factors. The formation of an intelligent judgment will be assisted by a study of reports of the United States Bureau of Soils, covering large parts of the valley, which are given in the following list: 
Lapham, M. H., Root, A. S., and Mackie, W. W., Soil survey of the Sacramento area, Cal.: U. S. Dept. Agr. Field Operations Bur. Soils, 1904, pp. 1049-1087, 1 map.

Lapham, M. H., Sweet, A. T., Strahorn, A. T., and Holmes, L. C., Soil survey of the Colusa area, Cal.: Idem, 1907, pp. 927-972, 2 maps.

Mann, C. W., Warner, J. F., Westover, H. L., and Ferguson, J. E., Soil survey of the Woodland area, Cal.: Idem, 1909, pp. 1635-1689, 2 maps.

Strahorn, A. T., Mackie, W. W., Holmes, L. C., Westover, H. L., and Van Duyne, Cornelius, Soil survey of the Marysville area, Cal.: Idem, 1909, pp. 1689-1740, 1 map.

Holmes, L. C., and Eckmann, E. C., Soil survey of the Red Bluff area, Cal.: Idem, 1910, pp. 1601-1656, 1 map.

The following reports of the United States Department of Agriculture treat of various phases of irrigation and the growing of crops:

Adams, Frank, Irrigation resources of California and their utilization: Office Exper. Sta. Bull. 254, 1913.

Fortier, Samuel, Irrigation in the Sacramento Valley, Cal.: Office Exper. Sta. Bull. 207, 1909.

Fortier, Samuel, and Beckett, S. H., Evaporation from irrigated soils: Office Exper. Sta. Bull. 248, 1912 .

Beckett, S. H., Progress report of cooperative irrigation experiments at California University farm, Davis, Cal., 1909-1912: U. S. Dept. Agr. Bull. 10, October 30, 1913.

Fortier, Samuel, Irrigation of alfalfa: Farmers' Bull. 373, 1909.

In the report of the Conservation Commission of California on the irrigation resources of the State, Adams ${ }^{1}$ gives the figures which have been combined in the following table:

Summary of agricultural, irrigated, and irrigable lands of California.

\begin{tabular}{|c|c|c|c|c|c|c|c|}
\hline & \multicolumn{2}{|c|}{ Agricultural Iand. } & \multicolumn{2}{|c|}{ Irrigated land, 1912.} & \multicolumn{3}{|c|}{$\begin{array}{l}\text { Estimated area that will ulti- } \\
\text { mately be irrigated. }\end{array}$} \\
\hline . & Acres. & $\begin{array}{l}\text { Per cent } \\
\text { of the } \\
\text { total for } \\
\text { Califor- } \\
\text { nia. }\end{array}$ & Acres. & $\begin{array}{l}\text { Per cent } \\
\text { of agri- } \\
\text { cultural } \\
\text { land. }\end{array}$ & Acres. & $\begin{array}{l}\text { Per cent } \\
\text { of agri- } \\
\text { cultural } \\
\text { land. }\end{array}$ & $\begin{array}{l}\text { Ratio to } \\
\text { area irri- } \\
\text { gated in } \\
1912 .\end{array}$ \\
\hline $\begin{array}{c}\text { Southern California.......... } \\
\text { Central California......... } \\
\text { Northern California (in- } \\
\text { cluding Sa cra mento } \\
\text { Valley) } . . . \ldots \ldots \ldots \ldots \ldots . . . . .\end{array}$ & $\begin{array}{l}6,070,325 \\
9,665,000 \\
6,201,000\end{array}$ & $\begin{array}{l}27 \\
44\end{array}$ & $\begin{array}{r}745,486 \\
1,959,355\end{array}$ & $\begin{array}{l}12.2 \\
20.2\end{array}$ & $\begin{array}{r}1,949,600 \\
4,300,000 \\
3,510,000\end{array}$ & $\begin{array}{l}32 \\
44\end{array}$ & $2 \frac{1}{2}$ \\
\hline All California. & $21,936,325$ & 100 & $3,188,541$ & 14.5 & $9,759,600$ & 44 & 3 \\
\hline $\begin{array}{l}\text { Sacramento Valley south } \\
\text { of Red Bluff, excluding } \\
\text { Stony Creek area......... }\end{array}$ & $3,305,000$ & 15 & 117,792 & 3.5 & $2,500,000$ & 75 & 21 \\
\hline
\end{tabular}

Note.-Irrigation figures are taken from the irrigation census of 1910, revised to 1912, and estimates of future irrigation are based on the most reliable data available.

It will be seen from the table that the Sacramento Valley contains 15 per cent of the agricultural land of the State. Only 3.5 per cent of the area was irrigated in 1912, but it is estimated that at least 75 per cent, or 21 times the present irrigated area, will ultimately be brought under water. These large possibilities have led to a rapid increase in the number of irrigation projects and an influx of men and capital from other parts of California to derive profit from the

1 Adams, Frank, Irrigation resources of California: California Conservation Comm. Rept. 1912, pp. 90-327. 
development of the land, their expectation being that the permanent future population will come from the Eastern States or from Europe.

Sacramento River and its tributaries have a mean annual discharge more than sufficient to irrigate all the valley lands and maintain navigation. ${ }^{1}$ However, gravity systems of irrigation from the rivers and streams involve heavy expenditures for diversion, storage, and the construction of laterals; legal difficulties arise; and adjustment to other water problems - those especially of navigation and flood control-is necessary. Such troubles are perhaps more apparent than real and will disappear when the common interests of the individual landowners and of the various communities are better recognized. In the meantime many enterprising men, unwilling or unable to wait for larger projects, have installed small private plants, pumping water from the streams and wells. Whole communities now depend on wells for their irrigation water.

The large irrigable area and the extensive use of ground water for domestic purposes, public supplies, and irrigation led the United States Geological Survey, in cooperation with the California State Department of Engineering, to undertake an investigation of which this report is a preliminary statement. Field work was begun by the writer in 1912 and continued in 1913 and 1914. Beginning in November, 1914, J. W. Muller, of the United States Geological Survey, spent two months in collecting statistics of pumping in Sacramento County. A report treating of the whole subject of ground water in Sacramento Valley will be published later.

The kindness and hospitality of people of the valley were a constant assistance in the progress of the investigation. The writer is also indebted to many local engineers and development companies for information of great value, but detailed acknowledgment to individuals can not be made in this preliminary report.

\section{GEOGRAPHY.}

The Sacramento Valley is a broad and fertile plain lying between the Sierra Nevada and the Coast Range and forming the northern part of the Great Valley of California, of which the San Joaquin Valley is the southern lobe. (See Pl. I.) The Sacramento Valley is 150 miles long and 40 miles wide, extending from latitude $38^{\circ} 15^{\prime}$ to $40^{\circ} 15^{\prime} \mathrm{N}$. It lies in the same latitude as the region from the mouth of the Potomac to Trenton, N. J.

The Sierra Nevada, on the east, rises gradually in low foothills, and a rich agricultural section, the "foothill belt," intervenes between the valley and the pine-clad summits of the range. To the west the ragged ridges of the Coast Range, covered with a sparse forest of oak and manzanita, shut off the cold winds and fogs of the Pacific. 


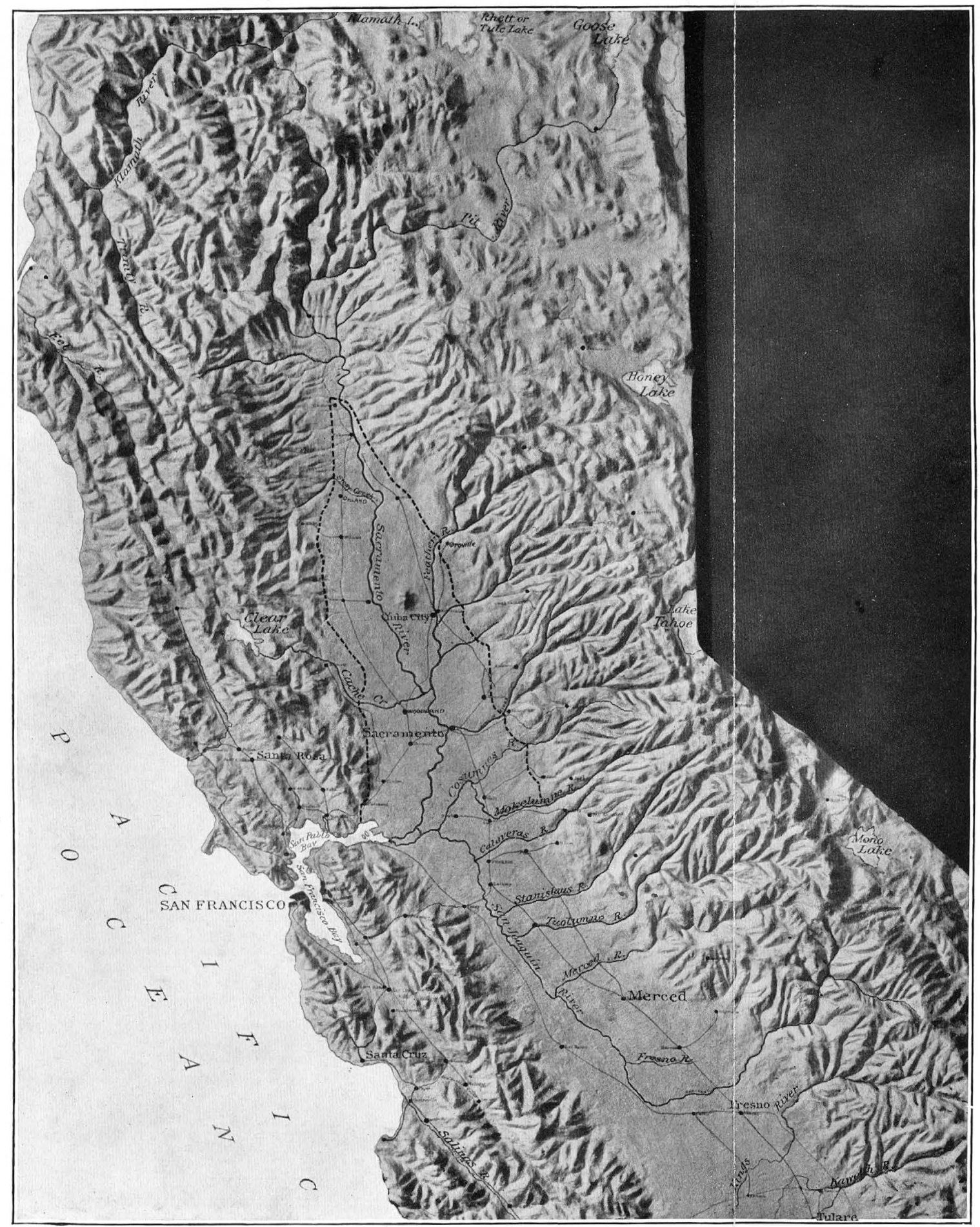

RELIEF MAP OF NORTHERN CALIFORNIA WITH OUTLINES OF SACRAMENTO VALLEY 
The valley has been accurately mapped by the United States Geological Survey on a scale of $1: 31,680$, with a 5-foot contour interval. The maps are published in named sheets including $7 \frac{1}{2}$ minutes of latitude and longitude, or an area about 8 miles long and 7 miles wide. On these maps each 160-acre tract is shown as an inch square, and elevations can be estimated within 1 foot. A single map of the whole valley, on a scale of $1: 250,000$, or about 4 miles to the inch, with a 25 -foot contour interval, has also been published by the Survey.

The inequalities of the valley plain are slight and are hardly perceptible at first glance, the 300 -foot contour line inclosing practically the whole valley area. Yet the minor elevations are of great significance in respect to the origin of the sediments and of importance in the life of the people. From Red Bluff to Hamilton Sacramento River runs in a flood plain from 1 to 5 miles wide, bounded by low bluffs or fairly steep plains. From Hamilton southward the river is bordered by flood basins, from which it is separated by a natural levee of choice farming land deposited by past floods. In high water, which occurs in the winter and spring, the river overflows, and depositing the coarse sediments on the natural levee, fills the basins at each side with water that spills from basin to basin and reaches the river farther south. The small tributary streams, especially those of the west side, discharge into the basins, depositing the coarser sediments in the plains and the finer in the basins. Only the larger streams reach the Sacramento directly, and these cross the basins confined between banks of their own building, similar to those of the main river.

Thus the valley includes (1) sloping plains, (2) shallow basins of heavy soils, (3) low ridges of loam and silt soils along the rivers, and (4) higher plains of older alluvium laid down during a previous cycle of deposition and now raised above the valley floor in low hills and rolling plains. These higher plains are much less productive of dryfarming crops than the near-by recent soils deposited by the same streams, but their slight elevation gives them immunity from frost, and their soils respond readily under irrigation.

Sacramento and Feather rivers are bordered by a thick tangle of cottonwood and willow jungle, heavily covered with the vine of the wild grape. The plains are grass covered, and near the streams are dotted with scattered oaks, which give the valley that "parklike appearance" mentioned by all the early writers. The basin lands were formerly covered by aquatic plants, the tule (Scarpus lacustris) being the most prominent. The tule has been largely burned off to improve the summer grazing, but the name clings as the popular designation of the overflow basins or "troughs." 
Towering above the flat lands are the Marysville Buttes, a landmark visible during clear weather from all parts of the valley. The buttes are a group of hills about 10 miles in diameter, with sharp central peaks, two of which, South Butte and North Butte, rise, respectively, 2,132 and 1,863 feet above sea level. The central area consists of andesite and rhyolite, crystalline rocks which are the solidified core of an ancient volcano. ${ }^{1}$ Around the core are upturned and baked shales and sandstones of Ione and Tejon age. The outer hills are composed of angular fragments of andesite and beds of volcanic ash, thrown out from the center during eruption. Narrow valleys filled with alluvium extend into the hills, but, unlike many of the tributaries of the main valley, these valleys have no terraces along their sides.

Sacramento River is affected by the tide as far north as the city of Sacramento, and is navigable in all seasons to Colusa. From Colusa to Red Bluff boats make regular trips only in the winter. The delta of the river begins south of Sacramento. This region is known as the island country, for here both the Sacramento and the San Joaquin break up into a number of winding channels or sloughs which surround irregular tracts of fertile land. Each river has a main channel south of the Montezuma Hills, to Suisun Bay, but before reaching the bay their waters unite through a number of sloughs, in which the direction of flow varies with the respective stages of the two rivers. Many of the islands surrounded by these channels are below sea level and are protected from floods by artificial levees.

As in other parts of California, the rainfall is concentrated in the five winter months. There is a gradual increase in amount up the valley, from 19 inches annually at Sacramento to 25 inches at Red Bluff. Slight increases are also noticeable from the center of the valley to the sides. The following table shows the average rainfall at three places in the valley near the north and south ends and the center:

Average rainfall in the Sacramento Valley, in inches.

\begin{tabular}{|c|c|c|c|c|c|c|c|c|c|c|c|c|c|c|}
\hline Station. & $\begin{array}{c}\text { Length } \\
\text { of } \\
\text { record } \\
\text { (years). }\end{array}$ & July. & Aug. & Sept. & Oct. & Nov. & Dec. & Jan. & Feb. & Mar. & Apr. & May. & June. & $\begin{array}{l}\text { An- } \\
\text { nual. }\end{array}$ \\
\hline $\begin{array}{l}\text { Sacramento. } \\
\text { Marysville. } \\
\text { Red Bluff... }\end{array}$ & $\begin{array}{l}65 \\
43 \\
36\end{array}$ & $\begin{array}{l}0.02 \\
\mathrm{Tr} . \\
.02\end{array}$ & $\begin{array}{r}0.01 \\
.01 \\
.02\end{array}$ & $\begin{array}{r}0.23 \\
.32 \\
.64\end{array}$ & $\begin{array}{l}0.80 \\
1.12 \\
1.33\end{array}$ & $\begin{array}{l}2.04 \\
2.23 \\
3.03\end{array}$ & $\begin{array}{l}3.90 \\
3.49 \\
4.48\end{array}$ & $\begin{array}{l}3.95 \\
3.98 \\
4.66\end{array}$ & $\begin{array}{l}2.81 \\
2.99 \\
3.53\end{array}$ & $\begin{array}{l}2.92 \\
2.85 \\
3.67\end{array}$ & $\begin{array}{l}1.57 \\
1.48 \\
1.81\end{array}$ & $\begin{array}{l}0.79 \\
.84 \\
1.23\end{array}$ & $\begin{array}{r}0.15 \\
.25 \\
.49\end{array}$ & $\begin{array}{l}19.19 \\
19.56 \\
24.91\end{array}$ \\
\hline
\end{tabular}

The winters are moderate, temperatures as low as $18^{\circ}$ above zero being recorded but twice in 64 years at Sacramento. These conditions are distinctly favorable to all kinds of agriculture and par-

1 Lindgren, Waldemar, and Turner, H. W., U. S. Geol. Survey Geol. Atlas, Marysville folio (No. 17), 1895. 
ticularly to the commercial production of grapes, figs, olives, citrus and deciduous fruits, and nuts.

The character of the climate is accurately reflected in the life of the people. With the beginning of the rains in the fall the grass springs up and cattle and sheep are brought down from the mountains, where they have passed the summer. The overflowed tule lands in the center of the valley are grazed only in the long, dry summer, and with the coming of the rains the cattle are moved to the higher plains. The grain farmer sows his wheat and barley in the fall and harvests them in the spring; this is called winter sowing. Or he may plow his land after the rains in the spring and let the plowed land lie fallow through the summer, to be planted before the rains in the fall; this is known as summer fallowing. Because the ground is too dry and hard to plow after the grain ripens, land that bears a crop can not be summer fallowed the same year, so that summer-fallow land has a crop only every other year. The concentration of the rainfall, with a shallow water table, enables all deeprooted plants to survive the summer, while the mild temperatures are favorable for delicate plants. On these conditions rests the orchard industry of the valley. All the deciduous fruits bear heavy crops and are rarely damaged by frost. The more delicate fruits and nuts - apricots, almonds, walnuts, olives, lemons, and orangesgrow well and are a commercial success in favored localities. The extensive grape industry is also dependent on the climate; the less hardy varieties of the vine may be grown, and the long dry season is favorable to the concentration of sugar in the grapes and to the drying of the grapes to make raisins.

Many districts in the valley are famous for certain special crops. This does not mean that these crops can not be grown with profit elsewhere, but only that they have been found to be especially well adapted to the particular soil, climate, and water of those districts. There is a tendency to magnify the differences between localities through prejudice and self-interest, but real differences exist that are sufficient to affect the quality of many crops. Without taking any natural advantage into consideration, it is obvious that, in growing an export crop, association with other growers of the same crop is beneficial, especially to the inexperienced, through standardization of methods of culture and marketing.

\section{WATER-BEARING FORMATIONS.}

PRE-TERTIARY ROCKS.

The Sacramento Valley is a basin whose sides and bottom are probably formed of the same granitic, schistose, and slaty rocks, of preCretaceous age, that compose the greater part of the Sierra Nevada 
and the core of the Coast Ranges. In this basin lie sandstones and shales of Cretaceous age, which are thin on the east side but thicker on the west. ${ }^{1}$ These formations carry little water and may be considered as an impervious floor on which the Tertiary and Quaternary water-bearing formations have been deposited.

The geologic history of the valley is long and complex, as is shown by the evidence derived from the rocks of bordering regions. An arm of the sea existed approximately in the position of the valley intermittently for a long time, but the depression that began in the Tertiary period, modified by Quaternary movements, gave to the valley its present shape.

\section{TERTIARY SEDIMENTS.}

During the Tertiary period two formations were deposited in this basin - the Tejon, which belongs to the Eocene series, and the Ione, which was originally described as Miocene but is now held by Dickerson ${ }^{2}$ to be Eocene. Neither of these is important as a waterbearing formation.

The Ione has not been recognized in wells of the valley, but deep wells near Lincoln obtain salty water from fine sand below a thick blue clay, or shale, which is either the Ione or the underlying Cretaceous.

\section{TERTIARY IAVAS.}

In Tertiary time lavas, breccias, and tuffs were extruded from volcanoes in the Sierra Nevada and extended down the slopes of the mountains and into the valley.

\section{ANDESITE BRECCIAS AND BASALT.}

The lava flows which cap the gold-bearing gravels in the ancient stream channels of the Sierra and which diverted the rivers into their present channels covered the Ione formation on the edges of the valley and now extend as a bed of lava grading into tuff beneath the more recent sediments in the valley, as is shown by the deeper wells of the east side. In some wells good water is obtained in sands and gravels that apparently occur at this horizon.

Basalt of similar history and origin caps the Ione formation in South Table Mountain, near Oroville, and in a group of hills farther north. The basalt is not known as a water bearer in the valley, but rain water which enters its jointed and porous outcrops seeps out at its contact with the Ione to form several perennial springs in the mountain and the basalt-capped hills near by.

1 Diller, J. S., Tertiary revolution in the topography of the Pacific coast: U. S. Geol. Survey Fourteenth Ann. Rept., pt. 2, p. 415, 1894. Lindgren, Waldemar, U. S. Geol. Survey Geol. Atlas, Sacramento folio (No. 5), 1894.

Dickerson, R. E., The Ione formation of the Sierra Nevada foothills, a local facies of the upper TejonEocene: Science, new ser., vol. 40, pp. 67-70, 1914. 
TUSCAN TUFF.

From Durham northward to Red Bluff and beyond the Sierra foothills are formed by beds of andesite lava, breccias, and volcanic ash aggregating 1,000 to 1,500 feet in thickness. These beds, which are known as the Tuscan tuff, consist of materials that were extruded from volcanoes in the vicinity of Lassen Peak. ${ }^{1}$

The formation is considered by Diller to be of Pliocene age, but small eruptions of similar material have continued through Quaternary time to the present day. That a long time was needed for the accumulation of these beds is shown by the presence of interbedded gravels whose smooth, waterworn pebbles of andesite and basalt were deposited by large graded streams that flowed over the volcanic plain and eroded its surface between successive volcanic eruptions. The main mass of the volcanic material to which the name Tuscan is given, was uplifted by a monoclinal fold (Chico monocline) extending along the border of the Sacramento Valley from Chico northwestward to Iron Canyon. This movement, which involves also the older alluvium, lifted the Tuscan tuff from 500 to 900 feet above the valley. In the plain thus formed a number of deep and desolate gorges have been cut by perennial streams, of which Antelope, Mill, Deer, Chico, and Butte creeks are the largest.

From the foothills of the Sierra the Tuscan tuff extends beneath the alluvium of the valley with diminished thickness and increasing fineness of grain. It is exposed about 12 miles west of Sacramento River along Thomas, Elder, and Redbank creeks as a pinkish tuff about 50 feet thick overlying the Ione formation. Little is known of the water-bearing properties of the Tuscan formation on the west side, but on the east side near Chico there are seven wells which penetrate the formation. The lowest yield is 600 gallons a minute. In the center of the valley shallow wells are likely to furnish sufficient water, but on the higher plains from Durham northward to Red Bluff, where the alluvium is thin and cemented, wells should be sunk to the Tuscan tuff if large supplies are needed. The dip of the formation is $10^{\circ}-15^{\circ} \mathrm{W}$. at the edge of the valley but flattens to horizontal in the center. Thus the depth to the formation within 2 or 3 miles from the outcrop east of Chico increases to 500 feet, but farther out in the valley it seems to lie at no greater depth. These relations are brought out in figure 1.

The depth of the formation beneath the valley has been estimated by interpretation of the well logs. The wells of the Chico Water Co. and the Morehead wells (see fig. 1) are certainly in the lavas at the depths indicated, but the Parrott well has a log which is not quite so

1 Diller, J. S., Tertiary revolution in the topography of the Pacific coast: U. S. Geol. Survey Fourteenth Ann. Rept., pt. 2, p. 412, 1894. 
easily interpreted. The "lava ash" reported at 377 feet and again at 399 feet may be only a fine silt and not a tuff bed of the Tuscan formation.

The inclined position of the Tuscan tuff is favorable for artesian water, but the absence of an impervious cover prevents the accumulation of the necessary head. Certain beds within the formation seem to be dry, and in many of the wells water stands slightly below the level of water in near-by shallow wells. In the wells of Stanford University east of Durham, however, the water stands 3.5 feet above the water table in the alluvium.

Drilling in the Tuscan tuff is difficult because the rock is hard and deep wells are necessary. The expense of drilling will be justified only where large supplies are needed or for stock and domestic water

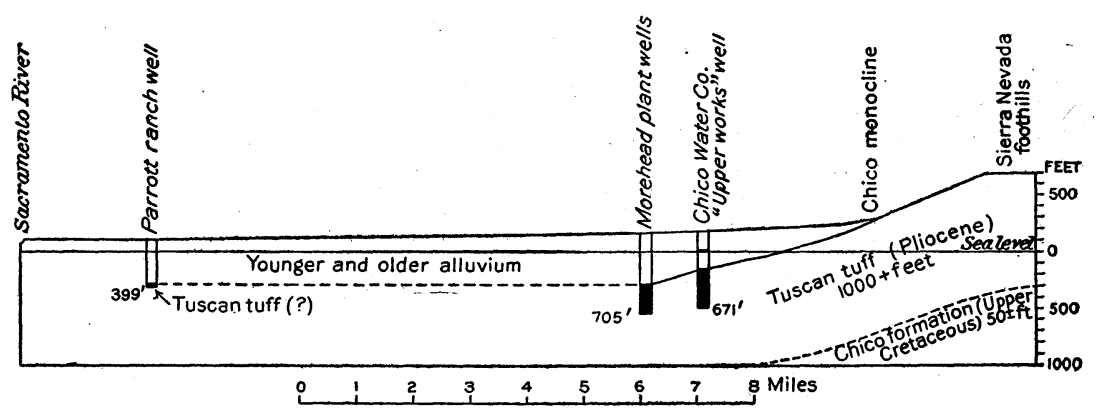

Figure 1.-Section through Chico, Cal., showing probable position of Tuscar tuff.

on the stony plains east of Vina, where shallow wells go dry in summer.

TUFF BEDS OF THE WEST SIDE.

Evidence of volcanic activity in the Coast Range is abundant. Ash beds and tuffs below the older alluvium and fine tuffs in the older alluvium of the west side indicate that in part at least this volcanism in the Coast Range was coincident with the Pliocene and Pleistocene eruptions of the Sierra Nevada.

\section{OLDER ALLUVIUM.}

The great volcanic eruptions of the Pliocene epoch were followed by uplift and erosion around the borders of the Sacramento Valley, but probably by continued deposition in the center. Deposition over the whole valley area then began and continued into Pleistocene time. The deposits thus laid down are known only where they have been exposed by later uplift on the borders of the valley, and when encountered in wells they can rarely be distinguished from the overlying younger alluvium. At the edge of the valley they rest on the andesite lava, the Tuscan tuff, and the Ione formation, in some places 
in apparent conformity, but in many places with evidences of extensive stream cutting before their deposition. In some localities the Tertiary beds have been removed and the alluvium lies directly on the granites and schists.

The older alluvium is of Pleistocene and possibly late Pliocene age and is differentiated from the younger alluvium only by the fact that it is now uplifted and dissected. It is composed of clay, sand, and gravel, and varies much in appearance and composition. It is characteristically red and is always redder than the neighboring younger alluvium, but the shade changes from place to place and samples from different areas have no superficial resemblance. This is due to the fact that the alluvium was deposited by streams varying in volume and permanence and draining areas of different types of rock. Only the deposits of tributary streams are exposed; the contemporary deposits of Sacramento River are now deeply buried. Four large divisions of the younger alluvium can be made and mapped - the southeastern, the northeastern, the southwestern, and the northwestern.

\section{SOUTHEASTERN DIVISION.}

The southeastern division of the older alluvium extends from Oroville southward to Lodi and comprises the deposits of Feather, Yuba, Bear, American, Cosumnes, and Mokelumne rivers. In Pleistocene time these strong streams trenched great canyons in the Sierra Nevada and discharged the eroded materials into the valley. The Sierra throughout this region is composed largely of granite and the alluvium is everywhere arkosic; that is, it contains undecomposed particles of feldspar and mica, with quartz, the constituent materials of this rock. The clay is red or brownish red, is tough and tenacious, and contains particles of iron-stained feldspar and muscovite mica. The sands are quartzose and carry a little feldspar and much mica, both muscovite and biotite. The gravels are usually well-rounded pebbles of the harder rocks. Quartz and quartzite pebbles predominate, but pebbles of granite, diabase, andesite, and schist also occur. In size they range from cobblestones near the mountains to pebbles an inch or less in diameter near the center of the valley. The gravels are in most places cemented with calcium carbonate, and "hardpan" is common throughout the formation. Hardpan composed of clay or sand cemented with lime and hydrous silicates of iron is commonly found near the surface. It is covered with a few inches to several feet of red soil, which has a superficial coat of pebbles due apparently to concentration by rain wash. Such soil and hardpan are characteristic of the higher plains. Irrigation and special treatment of the soil are necessary for full agricultural development of the rolling plains and hills of this formation. 
Wells in this formation should be drilled, as it is too hard for successful auger work except in certain favored places. Water is usually obtained from fine sand, as the gravels of the formation are commonly so cemented as to furnish but little water. Because the clays stand without casing the sand is usually pumped out and water is drawn from the cavities thus formed. Wells so constructed have a large seepage area and many of them, particularly in the lower part of the plains, are very successful.

\section{NORTHEASTERN DIVISION.}

The older alluvium of the northeastern division extends in irregular patches from Oroville to Chico and is more conspicuous from Chico along the east-side plains to Red Bluff. It is of the same age and was formed by the same processes as the older alluvium farther south, but as the comparatively short streams which furnished the sediments had their courses over the great blanket of Tertiary lavas that here mantle the Sierra the deposits are composed almost wholly of volcanic materials. The older alluvium of this part of the valley is thin, being nowhere over 60 feet thick where uplifted along the Chico monocline, and is composed chiefly of rather large, waterworn gravels, cemented by lime, with smaller amounts of brown clay and sand. The color of the formation as a whole is a deep brown, of slightly redder hue than the brown of recent deposits. Only small patches occur between Oroville and Chico, but north of Chico the older alluvium is the predominant surface formation on the east side of the valley. The surface is a treeless plain, covered with large and small stones, the finer material having been washed away by the rain. A thick grass springs up between the stones after the fall rains, and at such times the plains are used for grazing. Dug wells have been the common type in this area and have not been very successful. Drilled wells are more likely to develop water, but large supplies can not be expected from the older alluvium in this division.

\section{NORTHWESTERN DIVISION.}

The northwestern division of the older alluvium extends from Stony Creek to Red Bluff. It forms a prominent bluff that overlooks the river and, with the prevailing red color, gives the name to Red Bluff and to several other local features. The clays, sands, and gravels of the formation were deposited by the Sacramento and its western tributaries. The gravels are in places 2 to 3 inches in diameter and are composed of igneous and metamorphic rocks from the Klamath Mountains. The formation is thin where it rests on the Tuscan tuff about 12 miles west of the river and is over 400 feet thick near the river. The upper part laps over the east-side alluvium in the vicinity 
of Iron Canyon, and this part of the formation is therefore younger. The Sacramento was evidently gradually crowded over to the east during early Pleistocene time by the mass of material brought down by western tributaries. With movement along the Chico monocline the Sierra Nevada was uplifted and also the older alluvium. Contemporaneous with the Chico monocline were two cross folds at right angles to it. The uplift was so gradual that the Sacramento was able to cut down through the alluvium from both sides of the valley to the underlying Tuscan tuff, whose hard rocks now form Iron Canyon.

The alluvium of the northwestern division is not highly cemented, though it is necessary to use a drill in sinking wells in it. In a few places the gravels are dirty and cemented, but as a rule they are clean and are good water bearers. Excellent wells have been obtained in the first 300 feet in the vicinity of Red Bluff, and wells drilled recently near Corning are promising.

\section{SOUTHWESTERN DIVISION.}

In the southwestern division the older alluvium is composed of gray, brown, and yellow clay and fine sand, with local tuffaceous clays and ash beds. A reddish gravelly clay from a few inches to 25 feet thick occurs at the top of the formation and serves to distinguish it from the surrounding yellow and brown clays and loams of the younger alluvium. The formation rests on the eroded edges of Cretaceous and perhaps Tertiary rocks of the Coast Range, which have been beveled by erosion to a rather smooth plain. This plain extends from the alluvium up toward the mountains in successively higher ridges for a mile or more and is probably similar in origin and age to the plain that bevels the Cretaceous rocks in the northern part of the valley. ${ }^{1}$ The formation was uplifted in Pleistocene time by movement of two kinds. From Stony Creek to Williams the older alluvium was tilted as the mountains went up and the valley down, so that it now projects out of the modern alluvium in a thin and irregular fringe, nowhere over a mile wide. From Williams to Cache Creek the older alluvium forms a plateau from 200 to 500 feet above sea level, uplifted by movement due to faulting along a northwest-southeast line marked by the present front of the plateau. The minimum movement was at least 400 feet on the north and about 200 feet at Cache Creek. The same fault turns to the south at Cache Creek and extends, as shown by a line of low red hills, to Putah Creek. The plateau which in the southern part is known as the Hungry Hollow Hills, is thoroughly dissected by short streams at right angles to the fault. 
Another fault, en échelon with this one, starts at Esparto and, skirting the mountains, brings up the alluvium along the foothills to a point opposite Allendale, where the fault disappears. Farther south, around Elmira, the older alluvium comes close to the surface of the plains, which are only veneered with modern wash. It reappears in the Montezuma Hills, a well-dissected plateau of alluvium about 200 feet high on the west with a gentle slope to the northeast. These hills form the terminus of the plains and confine the waters of the Sacramento and San Joaquin in a narrow throat against the Mount Diablo Range, with Suisun Bay on the west and the island country on the east.

\section{YOUNGER ALLUVIUM.}

GENERAL CHARACTER AND DISTRIBUTION.

The deposition of the older alluvium was followed by uplift in both the Sierra Nevada and the Coast Range, which is regarded as part of the Pleistocene uplift of these ranges. The edges of the valley were bent up and the center gently bowed down. From Lodi to Oroville along the east side there was a gentle raising and tilting of the valley edge. The alluvium was lifted from 100 to 400 feet above the stream grades, causing each stream to cut a canyon of alluvium as it emerged into the valley. There were two pauses in the cutting of these canyons, marked by well-defined terraces. From Chico north to Red Bluff the movement was a sharp monoclinal flexure, which formed the Chico monocline and raised the Tuscan tuff about 900 feet. The alluvium, except where bent up in the fold, was raised between 50 and 150 feet above stream grade. The shallow valleys which traverse the plain of older alluvium show one terrace very prominently and in most places two.

On the west side from Red Bluff to Stony Creek each tributary valley which crosses the broad plains of the older alluvium shows terraces, as a rule the typical two. A general uplift took place at the north end of the valley, and there was less central deepening, well records indicating that the younger alluvium is less than 150 feet deep in the river bottoms. From Stony Creek south to Williams there was a sharp downward flexing, and the modern alluvium lies close to the mountains. From Williams southeast to Cache Creek the Hungry Hollow fault raises the older alluvium in the little plateau whose southern part forms the Hungry Hollow Hills. The streams that cross the plateau at right angles to the fault line have two well-developed terraces. Similarly Cache Creek shows two terraces where it crosses the fault and a similar set where it emerges from the mountains at Esparto.

With the uplift just described Sacramento River and its tributaries began the deposition of the younger alluvium, the material being eroded from the older alluvium or brought down from the mountains. 
The younger alluvium covers the central area of the valley ànd lies in narrow strips along the tributaries of the Sacramento. It varies in character, like older alluvium, but the deposits of the main river which it includes are exposed in addition to those of the side streams. The formation is probably nowhere in the valley more than 300 or 400 feet thick. Every high water adds to it, and this fact is so well understood that some farmers deliberately turn flood water on their land for the benefit derived from the "sediment."

The younger alluvium is the most productive water bearer of the valley formations. It is uncemented over most of the area and consists largely of sands and gravels. Many house wells draw water from the clays, but except under unusual conditions large supplies are derived only from the sand or gravel. Successful development consists in the search for sufficient sand and gravel and in the use of adequate well methods.

These beds were deposited by the present streams, and the coarsest and cleanest gravels were formed by the larger streams. But as these streams in building up the valley deposits have shifted their courses many times, their gravels are found over a wide area. The gravels are not continuous beds but irregular lenses and strings of material separated by sand and clay. Consequently the logs of adjacent wells are often very unlike. Where a stream is confined in a valley of older alluvium it is comparatively easy to sink a line of wells across the valley and determine the place where the maximum amount of gravel has been deposited. Where a stream debouches from the mountains directly upon the plain its deposits occupy a triangular area with the apex near the mountains. The gravels, representing old stream courses, extend in irregular wavy lines from the apex to the base. The largest amount of gravel is then at the mouth of the canyon, and the smallest near the mountains in the interstream areas.

Along the larger rivers wells draw from either sand or gravel and the gravels encountered are of the same size as those in the river bed at that place. Thus the Sacramento has gravels 3 to 6 inches in diameter near Red Bluff, 2 to 3 inches at Hamilton, 1 to 2 inches at Butte City, and about 1 inch at Colusa. From Colusa southward gravels are rare, but the sands are in many places coarse and gravelly, and even as far south as Rio Vista pebbles half an inch in diameter are found in the sands. Feather River carries gravels 6 to 8 inches in diameter at Oroville, but at Marysville most of its load is sand.

LOCAL CHARACTERISTICS AND WATER DEVELOPMENTS.

Ground water has been used for irrigation of the bottom lands of the Sacramento near Tehama, Butte City, and Colusa. The light, porous soils of the river bottoms require large heads of water in order 
to cover the land, and consequently large plants are needed. Many owners having riparian rights pump from the river with lifts about the same as those pumping from wells. The decision whether any particular tract of river bottom land should be irrigated from the river or from wells rests simply on the cost of wells relative to the cost of access to the river, the damage from floods, and losses in the ditches passing through sandy land from the river to the fields. Wells can be made cheaply by the ordinary methods as far south as Colusa, but south of this point the gravels are finer and sand screens more efficient than those customarily used should be installed.

In Solano County from the Montezuma Hills northward the size and amount of the gravels increase, and in the neighborhood of Dixon beds of rather coarse gravel are common. These gravels are mixed with sand, but include pebbles from 1 to 3 inches in diameter and are similar to those in the present bed of Putah Creek. This stream is prevented from swinging to the north by the low red hills extending south from the Hungry Hollow Hills and seems to have deposited most of its material south of its present channel. A number of dry sloughs or old channels extend southeastward from Putah Creek and are indicated by the many changes in the course of the creek in past time. Well conditions seem to be especially favorable in the triangle between Dixon Ridge, Putah Creek, and Yolo Basin.

In Yolo County, between Putah and Cache creeks, the younger alluvium is divided into east and west portions by a strip of older alluvium thrown up by the Hungry Hollow fault. The low red hills thus formed act as a partial dam to ground waters originating near Cache Creek. In consequence ground water is within 6 feet of the surface over a number of areas west of Plainfield and east of Citrona. Owing to the shallowness of the water the land is alkaline, but it affords admirable sites for pumping plants on account of the low lifts. House wells indicate that good gravel will be found. Pumping of ground water here would tend to drain and reclaim the alkaline land.

Few wells have been put down between Davis and Woodland east of the fault, but these few indicate the presence of good gravels, and the supply of water should be adequate except in the immediate vicinity of the red hills.

Large plants are characteristic of the district around Woodland and across Cache Creek on Knights Landing Ridge, where coarse, clean gravels are found at moderate depths. These gravels were deposited by Cache Creek and are widely distributed on both sides of the stream. The amount of water obtained is dependent on the thickness of the gravel bed and the kind of well screen used. For the irrigation of any particular tract prospect wells should be sunk, and when the thickness and coarseness of the gravels are learned suitable sicreens should be inserted, as described under "Well problems." East of 
Woodland, at the border of Yolo Basin, flowing wells are not uncommon, but the flows are small and of no commercial importance.

From the Cache Creek delta to the fan of Stony Creek the Recent alluvium of the plains was deposited by comparatively small streams. The gravels are small in amount, not very coarse, and locally mixed with clay. The yield of wells is smaller than near Woodland, but with the use of better well methods adequate supplies can be obtained. West of Arbuckle the plains are steep and the water table deeper than in any other part of the younger alluvium. The primary lift of 60 to 75 feet should not, however, prevent the profitable use of ground water on orchard crops. Considerable pumping is done on the delta of Cortina Creek at Williams and along Willow Creek at Willows.

North of Willows to Stony Creek the younger alluvium consists of the deposits of Stony Creek. These coarse materials are good water bearers and wells can be cheaply developed over the area. At the south edge of the Stony Creek fan, near Germantown and Willows, artesian water has been found at a depth of about 800 feet. The flows vary from a few gallons to 200 gallons a minute, and while the water is of value for stock and domestic use it has not yet proved more economical than pumped water.

North of Stony Creek the younger alluvium lies in little valleys and swales in the rolling plains of the older alluvium. Shallow wells obtain water for irrigation, especially around Corning and near Thomas Creek. The gravels are in places full of clay, and partly for this reason and partly because of poor methods the yield of wells is small, from 50 to 200 gallons a minute. The tight soils, however, make the use of small quantities of water possible, especially in the irrigation of orchards.

On the east side of the valley the younger alluvium is inconsiderable in amount over the plains north of Chico. Southwest of the town, on the Chico Creek fan, water is obtained in shallow wells in the alluvium, but near the mountains the alluvium is very thin and not a good water bearer. Through this region, however, large supplies may be obtained from the underlying Tuscan tuff. (See p. 9.)

In the region south of Chico the east-side plains are largely formed of younger alluvium as far south as Marysville. In the upper part of Butte Basin gravels are derived from the old courses of Butte and Dry creeks. Although little development has taken place here it is thought that prospect wells will locate gravels and sands in the first 200 to 300 feet, and that from these beds good wells can be obtained. In the Biggs-Gridley district the younger alluvium has been deposited by Feather River, and coarse, clean gravels are found in wells. 
In the eastern part of Sutter Basin a large pumping district has sprung up around and south of Yuba City. Water is found in sand, usually in sufficient amount within the first 200 feet. The clays are tough and form a good roof, so that the sand may be pumped out and wells obtained very cheaply. Farther west toward the trough and south near Marcuse and Chandler the water is likely to be poorer in quality. Most of this water, however, is usable for irrigation.

East of Feather River the younger alluvium fringes the river and extends into the valleys of the minor streams. The gravels are very coarse as far south as Honcut Creek, and considerable development is taking place. From the Honcut to Yuba River the gravels are finer and many wells draw water from sand. The water table is shallow and the consequent low lifts should induce pumping.

In the plains south of the Yuba separation of the younger and older alluvium must be rather arbitrary. Both formations are water bearers. The whole plains area from the Yuba south to American River is susceptible of development. In the lower plains water will be obtained largely from the younger alluvium, and in the higher plains from the older alluvium at depths less than 300 feet. The deep wells of the Natomas Consolidated of California in Reclamation District 1001 have shown the occurrence of large supplies of water between 500 and 800 feet. Near the foothills deep drilling has not been successful. The valley formations are thinner, and the Ione formation and probably the Chico also are likely to furnish salty water.

South of American River thelower plains broaden out. In theseplains it is difficult to distinguish between the two kinds of alluvium. In a general way the redder, higher knolls are older alluvium. The higher plains are formed of older alluvium capping Tertiary beds. In the lower plains and the flood plains of American, Cosumnes, and Mokelumne rivers good wells are obtained very cheaply. In general the water comes from sand beds between cemented gravels and clays which stand well and form a good roof. A very large amount of development has taken place, and all the lower plains may be considered proved territory for ground water. Wells with yields large enough for orchard irrigation can probably be obtained in the higher plains, but near the mountains the alluvium is thin and prospects are not so good.

\section{ORIGIN AND MOVEMENTS OF THE GROUND WATER.}

\section{THE WATER TABIE.}

Throughout the valley the alluvium at a depth of a few feet is saturated with water. This water is known as the ground water and fills the interstices of the ground to an indefinite distance downward. In general, the earth's crust becomes more compact in depth, and 


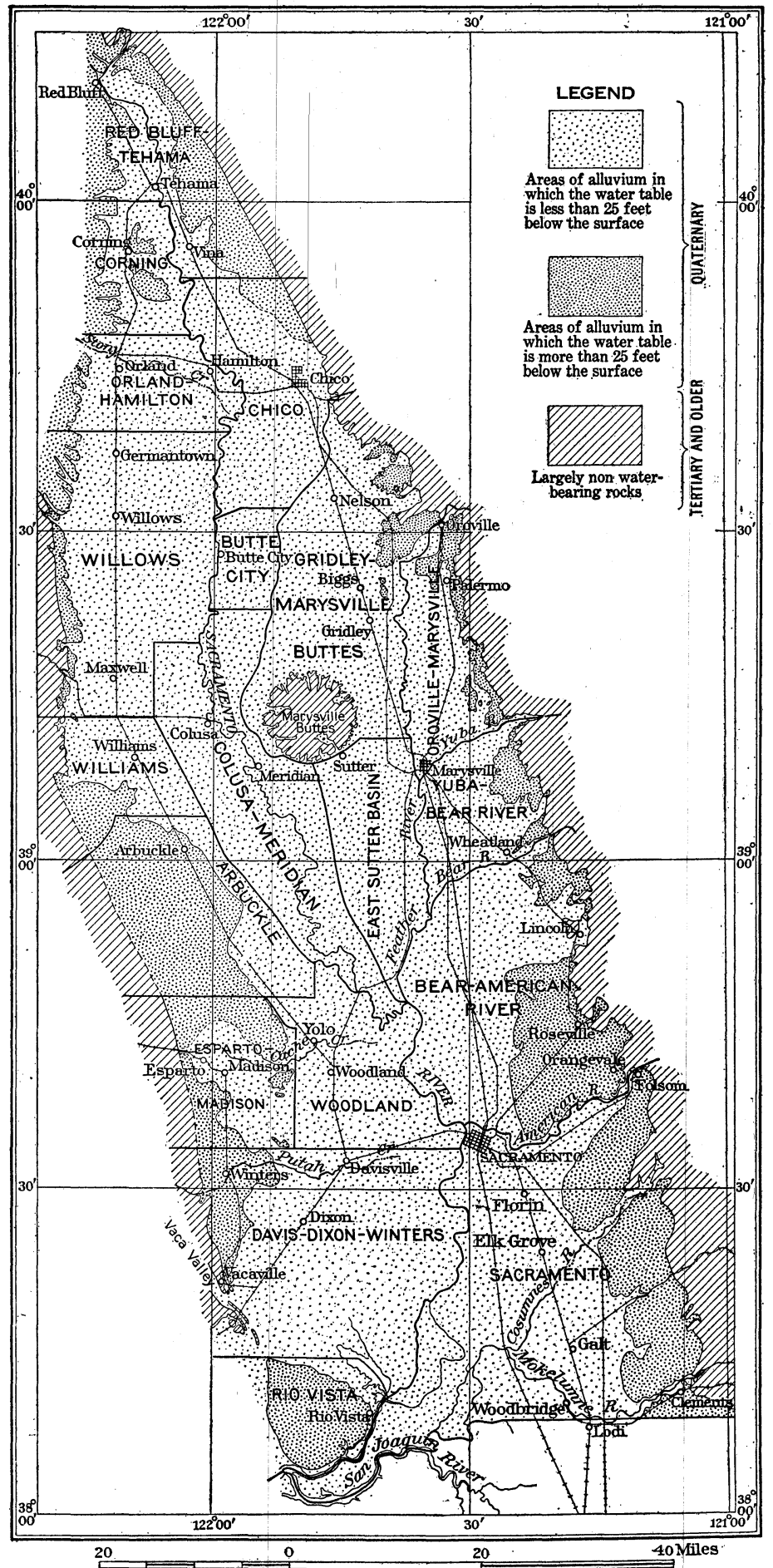

OUTLINE MAP OF SACRAMENTO VALLEY, CAL., SHOWING PUMPING AREAS AND DEPTH TO WATER. 
in every region there is a depth at which the pores of the rocks are so small that they yield little or no water. The top of this saturated zone is called the water table. It is the level at which water stands in shallow wells.

The Sacramento Valley is remarkable for the large area in which the water table stands close to the surface. During the summers of 1912 and 1913-two dry years-less than 20 per cent of the valley had a depth to water of more than 25 feet. Water was more than 25 feet deep over the plains area on both sides of the river north of Hamilton; in a fringe of interstream areas of older alluvium, or "red lands," on both sides of the valley; in the steep fan west of Arbuckle; and in the apricot district around Winters. These areas are outlined on the map (Pl. II). In the rest of the valley water stood at depths between 6 and 25 feet.

The water table slopes from the sides of the valley toward the center and from the north to the south. The grade is slightly less than that of the land surface, so that water is shallower in the basin areas than toward the hills. In the northern part of the valley the ground water slopes toward Sacramento River, and except during flood times escapes to and feeds the river. From Hamilton southward the water table slopes to the basins from the plains and also from the river down the slope of the natural levees to the basins. The grade in the basins from north to south is very slight, so that the ground water is practically stagnant in these areas. Thus the fluctuations of the river affect only the wells near the river bank.

\section{LOSSES OF THE GROUND WATER.}

It is a matter of common observation that water in wells rises in the winter and falls in the summer. This means that a large amount of water is taken into the ground in winter, which is lost again in summer. This water is supplied by local rainfall, percolation from stream channels, and winter floods. Loss occurs by movement down the slope of the water table to seeps and sloughs in the basin lands, where the water evaporates. Evaporation also takes place from moist lands where the ground water stands less than 8 feet from the surface. With evaporation the dissolved salts are left in the ground and form "alkali" land.

\section{AIKAII.}

Although there are large areas in the valley with a shallow water table, favorable to evaporation and the accumulation of alkali, only comparatively small areas are unfitted for agriculture from this cause. This condition seems to be due to the following reasons:

1. The ground waters are of good quality. The east-side waters contain from 100 to 250 parts per million of dissolved substances, 
mostly calcium and the bicarbonate radicle, and the west-side waters contain from 200 to 600 parts per million of dissolved substances, largely calcium and the bicarbonate and sulphate radicles.

2. The water table is very flat over the basins, and movements of the ground water are sluggish. Water is supplied more freely at the bases of the slopes, and for this reason the principal concentration of alkali occurs at the edges of the basins. This is particularly the case on the west side, where alkaline patches and areas of salt grass border the basin along its western edge. The distribution of alkaline land on the west side of the valley may be obtained from the soil reports of the Colusa and Woodland areas. ${ }^{1}$

3. The heavy winter rains leach out much of the salts concentrated at the surface. Similarly flood waters wash out the salts in overflowed lands, and on the edges of the plains the same waters deposit mud or sediment, which often covers up the alkali.

\section{FLUCTUATIONS OF THE WATER TABIE.}

The fluctuations of the water table are large. The rise begins in September and is gradual until the coming of the rains, when the rate

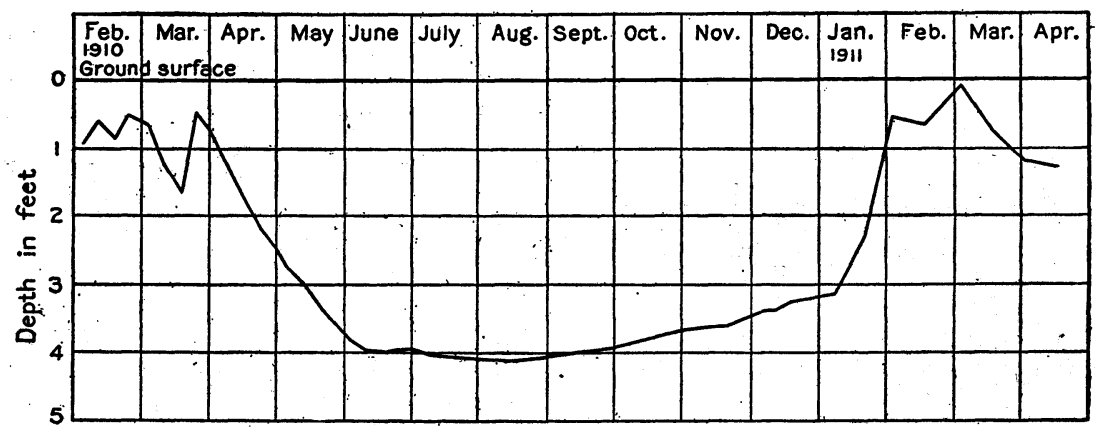

Figure 2.-Fluctuations of the water table in 24 wells in Colusa Basin, Cal.

increases until March. From March the water falls until, in the later part of June, it reaches the summer level, which is nearly constant except when affected by pumping. The characteristic fluctuations in the basin lands are shown in figure 2, which gives the average of the depths to water observed weekly in 24 wells in Colusa Basin. The curve is very similar to those given by Lee ${ }^{2}$ for the moist lands in the Owens Valley. The summer low is, however, more drawn out and the rise and fall before and after the winter rains are much sharper. The rise of ground water in September before the

1 Lapham, M. H., and others, Soil survey of the Colusa area, Cal.: U. S. Dept. Agr. Field Operations Bur. Soils, 1907, pp. 927-972. Mann, C. W., and others, Soil survey of the Woodland area, Cal.: Idem, 1909, pp. 1635-1689.

2 Lee, C. H., An intensive study of the water resources of a part of Owens Valley, Cal.: U. S. Geol. Survey Water-Supply Paper 294, pp. 80-81, 1912. 
winter rains seems to be due to a decrease in evaporation with cooler weather. The decreased evaporation is largely effective in the border lands. A rise of ground water in the basin areas then takes place which with lessened draft produces a general rise in all the wells of the valley.

In the plains area, where the depth to water is 15 to 25 feet in summer, the winter rise brings the water within 5 to 15 feet of the surface.

\section{AMOUNT OF GROUND WATER.}

The total quantity of ground water in the valley is very great. The sands and gravels contain from 20 to 40 per cent of water, the clays perhaps more. Because the pore spaces of the sand and gravel are much larger than those of the clay the rate of flow through these materials is much greater and they become for practical purposes the water bearers. The sand and gravels are distributed through the alluvium, which thickens from less than 50 feet at the edge of the valley to 500 feet or more in the center.

The rapidity of the winter rise and its sensitiveness to rainfall afford the best indication of the quantity of water available for pumping, for the available ground water in any district is the average amount which, falling as rain, percolates into the soil or, being collected in the mountain valleys, is carried to the plains by torrential streams and there sinks into the ground, less the amount which emerges through seepage and evaporation before or during the pumping season. It is very difficult to estimate this amount. In the neighborhood of Dixon, where pumping for irrigation had been practiced for 12 years and on a large scale for the last 5 years, water was lower in the wells in the summer of 1912 than it had been for 12 years. The water stood about 5 feet below the normal August level, according to the observations of many irrigators, necessitating the deepening of pumping pits and the lowering of pumps. This sinking of the water table was not due entirely to pumping but in part to the excess of natural loss over gain because of the small rainfall of the previous two winters. A lowering of the water level in wells, amounting probably to an average of 2 or 3 feet, had been commonly noticed by well owners throughout the valley in the summer of 1912, and it may be inferred that the additional lowering of 2 or 3 feet near Dixon in the same season was due to the withdrawal made by the hundred plants in the immediate vicinity of the town.

Changes in water level have a large bearing on the operation of pumping plants. The machinery is likely to be flooded in the spring, but in August, when water is most needed, the suction of the pumps may be so great as to decrease the supply seriously. This problem is discussed more fully under the heading "Pumping problems" 
(p. 37). The plant of T. T. Eibe, near Dixon, will serve as an example. The well is 97 feet deep and is cased to the bottom with galvanized-iron casing 10 inches in diameter. It is at one side of an 8 by 8 foot cement pit 8 feet deep and is equipped with a 5 -inch horizontal centrifugal pump connected by belt in an inclined belt way to a 12-horsepower gasoline engine. When this plant was visited in October, 1912, the water stood 7 feet below the cement floor. Mr. Eibe says that it has never before been lower than 2 feet below the floor and that in the winter of 1907 it stood 2 feet from the top of the pit. Even in June, 1912, there was 4 feet of water in the pit, and in order to do any pumping it was necessary to replace the belt with a chain drive. In this place, then, there was in the dry year of 1912 a variation in level of 11 feet in less than five months. In wet years the amount of fluctuation is probably not so great because summer lowering from natural causes is about the same each year, but with increasing withdrawals of water by pumping the volume of dry ground will be increased and consequently also the absorption and storage of water during wet winters.

The winters of 1911 and 1912 were dry, less than half the normal rainfall being recorded at most of the valley stations. In consequence the winter rise of ground water was smaller than usual, and in the summer of 1913 the water table was exceptionally low. With the heavy rains of the succeeding winter, however, recovery was general, even in regions of heavy pumping.

These conditions are brought out in figure 3, which is a record of water levels in the "Irrigation investigations" well at the California University Farm at Davis. The upper curve in the figure shows the depth to the water level when the well is not in use, and the lower curve shows the depth when the pump is operated. The observations were made on the first of each month by S. H. Beckett, irrigation engineer, who generously furnished the record. The monthly rainfall at Davis, obtained from the United States Weather Bureau, is plotted for comparison.

On heary pumping the water in a well lowers, and this lowering is called the "drawdown." The water is also lowered in the ground for some distance around the well. Wells near by are often affected and, if shallow, may be rendered useless. This depression of the water table or "cone of influence" is very large and has a flat angle when the supply of water is scanty, but is small and has a steep angle when the water is plentiful. If the ground water were simply a pool in the pore spaces of the ground this cone of influence would gradually extend and become flatter until the whole body of water would be permanently lowered, but the ground water is constantly in motion, receiving its increment from the rains and moving toward the center of the valley, where it is lost by seepage and evaporation. Its level 
rises and falls according to the amount that is passing by. When the water table at any point is depressed by pumping, movement takes

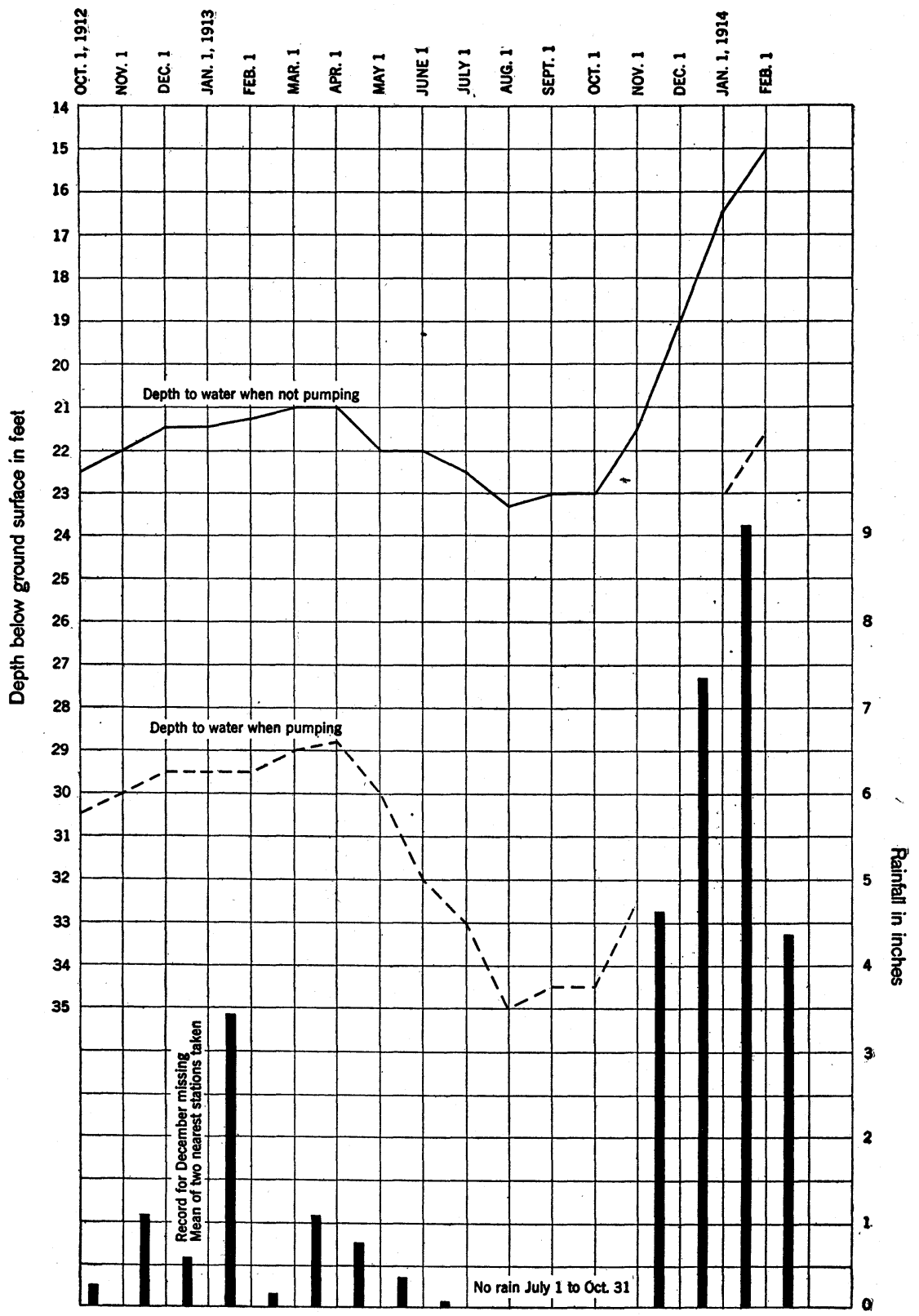

FiquRE 3.-Rainfall and fluctuations of the water table at Davis, Cal., Oct. 1, 1912, to Feb. 1, 1914. Data furnished by S. H. Beckett.

place toward that point from all directions; but the largest amount of water will come from the place where the flow originates, for on that side the head is greater. 
Figure 4 shows the position of the water table near Yuba City in September, 1913. The general slope indicated by contours from Feather River west and south to Sutter Basin is normal to the locality, though the water table is from 2 to 3 feet lower than usual because of the dry season. The principal pumping was done along Gilsizer Slough, and here the water table was lowered a maximum of about 5

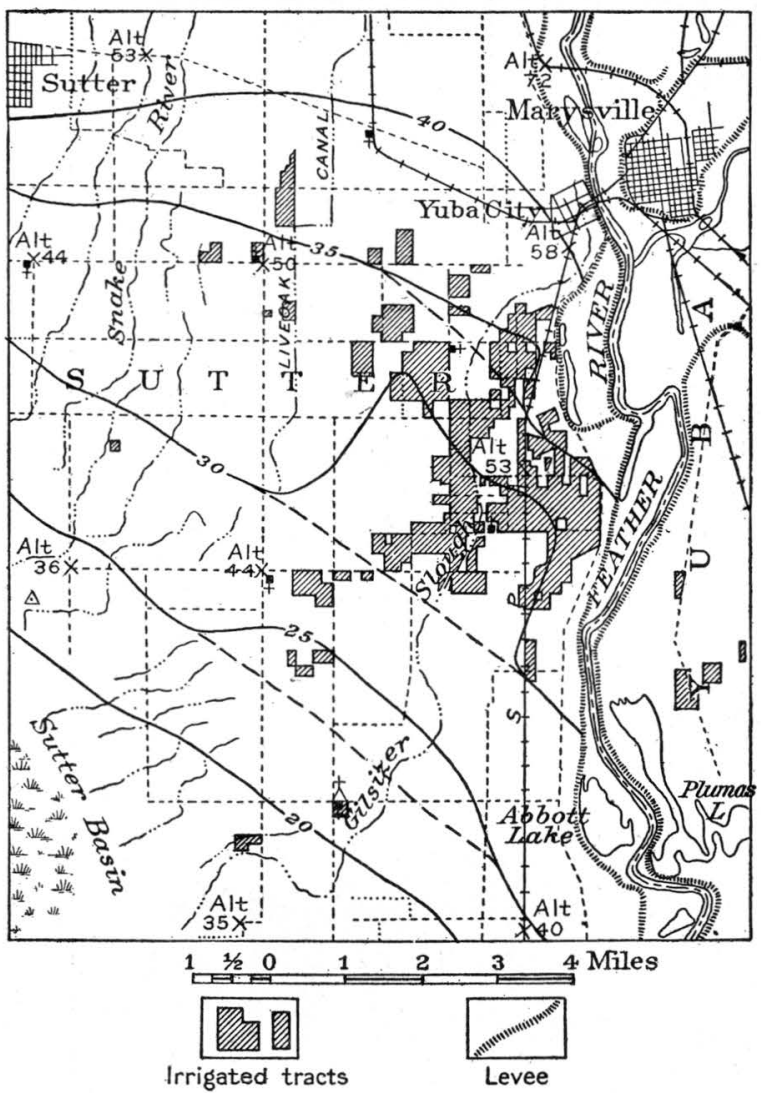

Figure 4.-Position of water table near Yuba City, Cal., September, 1913. Unbroken lines show contours of water table (feet above sea level); broken lines indicate probable position of contours of water table if there had been no pumping. feet in addition to the general lowering, as is shown by the backward swing of the contour lines. The approximate position of the water table if there had been no pumping is indicated by broken lines.

Similar lowering of the normal groundwater level was found along Knights Landing Ridge northeast of Yolo. The depth to water inJ.R. Fisher'swells was 24 feet in July, 1900. ${ }^{1}$ These wells were pumped with a 6 -inch centrifugal pump operated by a 17-horsepower steam engine from 1898 to 1900 , when the pumping plant was removed. On September 29, 1912, the water stood 23.8 feet below the top of the pump pit. Mr. Fisher stated that early in the spring of 1913 the water was only 21 feet below the surface and that in normal winters the water rises within 10 to 15 feet of the surface. On June 27, 1913, the depth to water was 39 feet. In the spring of 1913 a 3 -inch centrifugal pump operated by a 10-horsepower motor was insta!led and 10 acres of alfalfa was

${ }^{1}$ Chandler, A. E., Water storage on Cache Creek, Cal.: U. S. Geol. Survey Water-Supply Paper 45, p. $25,1901$. 
irrigated. These wells are a quarter of a mile south of the St. Louis pumping plant of the Sacramento Valley Sugar Co., which was operated for about 70 days during the season of 1913 at a capacity of 7,000 gallons a minute. On a temporary shutdown of the St. Louis plant Mr. Fisher observed the water rise 22 inches in his wells.

When the pumping plant of A. W. Dick \& Sons, 2 miles north of the Fisher plant, was installed, January 1, 1913, the pump, set in a pit 15 feet deep, primed at a vacuum of 2.5 inches of mercury, which is equivalent to a depth of water of 2.8 feet below the pump; in July it primed at a vacuum of 12 inches of mercury, indicating a lowering of the water level to 13.5 feet below the pump, or a net lowering of 10.7 feet. In the house well of B. Weiss, $1 \frac{1}{2}$ miles west of the Dick plant and $1 \frac{1}{4}$ miles from the nearest pumping plant, the water level was 12.9 feet below the top of the casing on October 1, 1912, and 15.5 feet on July 1, 1913, a lowering of 3.6 feet. Lowering was not evident near the river, as is shown by the fact that in C. A. Piper's well, near Knights Landing, the water level was 17.7 feet below the top of the casing on September 7, 1912, and 17.6 feet on July 1, 1913.

These and other observations show that pumping produces only a local depression of the water table and that the winter rise in normal years is rapid and effective. General lowering of the ground water may be expected in the summer, and it will be large during periods of deficient rainfall. Heavy pumping may be expected to create still further depression, which, if the whole valley were irrigated by pumping, would increase the general lowering. However, because pumping increases the volume of dry soil capable of receiving and retaining water, it thereby increases the amount of water that is stored underground in the succeeding rainy season. ${ }^{1}$ Wells in or near land that will in the future be irrigated from ditches will have a decreased lift after irrigation is begun, because of the rise of ground water that accompanies the ordinary wasteful methods of applying water. Along the edges of the basins, within reclamation districts and in other localities where the ground water stands very near the surface, lowering of the water table by pumping will be beneficial.

The economic limit for pumping will be reached when the groundwater level is so depressed at the end of two or three dry seasons that the cost of the increased lift absorbs the profit from the crop. In view of the high lifts common in southern California, where water is being pumped for irrigating alfalfa with a lift of 100 feet and for irrigating citrus fruits with a lift of 200 to 400 feet, ${ }^{2}$ it would seem that a very considerable increase in the number of plants can be made in the present pumping districts of the Sacramento Valley.

1 Smith, G. E. P., Arizona Univ. Agr. Exper. Sta. Bull. 64, p. 189, 1910.

2 Tait, C. E., The use of underground water for irrigation at Pomona, Cal.: U. S. Dept. Agr. Office Exper. Sta, Bull. 236, p. 96, 1911. 


\section{GROUND-WATER DEVELOPMENT.}

\section{GENERAI CONSIDERATIONS.}

The development of a pumping project has three main phasesprospecting to locate the best available water-bearing beds, sinking wells, and installing pumping machinery. Although it is possible from geologic evidence to determine for any part of the valley the general distribution and character of the water-bearing beds, the precise location of these beds and their value as sources of water can be determined only by sinking wells. Test wells should therefore be put down to determine the best place to locate permanent wells, although the advantage of having the plant at the highest point of the tract to be irrigated may cause the acceptance of poorer gravels at this point. The cost of this preliminary work is small in comparison to the cost of developing water in a poor location that is arbitrarily chosen, or in comparison to the losses that result from an inadequate supply.

\section{WELI PROBLEMS.}

\section{DUG WELLS.}

The early settlers of the valley depended altogether on dug wells, which penetrated just to or slightly below the water level. As sources of water for domestic uses most of these wells have been abandoned, because of the difficulty of keeping them in a sanitary condition.

In the development of supplies for irrigation, dug wells are suitable for obtaining the largest possible amount of water from a single water-bearing bed close to the surface. In the valleys in the older alluvium and along the foothills there are places where the principal water is in such a bed. In such places dug wells are valuable and sometimes the only suitable method of obtaining ground water, but in most parts of the valley bored or drilled wells are more satisfactory.

The two most serious difficulties connected with the sinking of dug wells are casing the sides of the hole and disposing of the water after the water level is reached, so that digging may proceed.

In most localities where such wells are valuable, as in the neighborhood of Chico, on the high plains of the east side, and in the plateau of older alluvium on the west side, the ground is sufficiently tight to stand without support until a considerable hole has been dug. In these localities a timber or concrete lining can be built in sections as digging progresses. The clays encountered on the east-side plains are so tough that they have stood in the walls of certain dug wells for 30 years without curbing. Pick marks made in digging are still visible in the walls of some of these old wells. 
Where the material is soft a square or annular shoe of timber protected with sheet iron should be constructed and a masonry or concrete wall built upon it. As the earth is dug out at the center the curb settles by its own weight and the wall may be successively added thereto. Care should be exercised to keep the curb plumb, to prevent jamming.

When the water table is reached in digging a well means must be provided to pump out the water before the well can be dug deeper. A pump with a flexible suction hose and foot valve should be obtained, and, if possible, this pump should have a larger capacity than one that is to be installed permanently. When the pump used in sinking is the one the well is expected to supply it should be overspeeded to increase its capacity above normal. Where electric power is available the pump and motor may be lowered on stages set inside the curbing. A direct-connected outfit will need only one stage, but will take up more room than a belted outfit and there is no way to increase the speed of the pump. With gasoline or steam power the engine should be set near the edge of the pit so that the belt pulley will project over the opening and give a vertical drive, or a jack shaft and idlers should be used. As the pump is lowered increasing lengths of belt must be inserted.

The yield of dug wells decreases rapidly with a lowering of the water table in dry seasons, and consequently they should be sunk in August, when the water is lowest, and should be carried as far below the water table as practicable.

\section{BORED WELLS.}

The commonest method of sinking wells is with the use of augers similar to those used for making postholes. This rather primitive method has been abandoned in most parts of the United States, ${ }^{1}$ but in the Sacramento Valley it is competing successfully with the more modern methods. Wells have been sunk to depths of 350 feet with augers, but at this depth the torsion of the rods and the time required to insert and remove them are so great as to make the work difficult and slow. Cemented beds or large bowlders are difficult or impossible to handle. The best success is attained in localities where only clay, sand, and gravel are encountered and in wells from 30 to 150 feet deep.

The rig consists of a three-legged derrick with a windlass for raising and lowering the tools by a rope that passes through a pulley at the top of the derrick. The tools consist of augers, reamers, sand pumps,

1 Bowman, Isaiah, Well-drilling methods: U. S. Geol. Survey Water-Supply Paper 257, pp. 70-78, 1911. This paper contains an adequate discussion of the various methods of sinking wells and should be in the hands of every well driller and every person intending to make any large well development. Copies may be purchased from the Superintendent of Documents, Washington, D. C., for 15 cents, 
a worm screw, and a chisel-bit drill. The augers vary with every outfit, and are usually made by the local blacksmith. They are from 4 to 8 feet long and from 4 to 12 inches in diameter. Hollow steel rods are used to turn the augers, to which they are connected either by a screw coupling or a square pin and socket.

In the simpler outfits boring is done by hand. One of the rods, which is kept always above ground, has a series of holes in which a horizontal drive bar is inserted. The men seize this bar and turn the auger by walking around the well. Sand and gravel are removed by the sand pump, as in ordinary cable drilling.

Within the last few years a number of power auger rigs have come into the field. There are two types-one in which a rotary plate is mounted on the ground, as in hydraulic rigs, and another with an overhead rotary. In either type a gasoline engine is mounted on the truck, which carries also a mast, or derrick, and a hoisting drum. The use of power has brought about minor modifications in the tools, but the results accomplished are about the same. The power rigs have reduced the cost of wells by reducing the labor and time required for sinking, but no reduction in price has resulted, because a better grade of work in casing and finishing a well is now required of the contractors.

Prices vary from place to place, but in general well borers charge from $\$ 1$ to $\$ 2$ a foot for 10 or 12 inch wells not more than 150 feet deep when the well owner pays for the casing. For the greater depths or where unusual difficulties are expected $\$ 10$ a day is the usual charge.

\section{DRILLED WELLS.}

Hydraulic methods have been but little used in putting down wells in the Sacramento Valley, though there is no good reason why this method should not be suitable for sinking deep wells throughout the central and western parts of the valley.

Two types of percussion or churn drills are in use-the ordinary portable rigs of various manufactures and the California or "mudscow" rig. The latter has many manifest advantages in unconsolidated deposits, and the double slip-joint or stovepipe casing which is used is advantageous where gravel is encountered. The ordinary portable rig is more adaptable to various conditions and can handle hard rock and cemented beds to better advantage. It has a large field of service in the east-side plains and in the areas underlaid by the Tuscan tuff.

Prices are higher for drilled wells than for bored wells, and the driller expects to put down deeper wells and do work of a higher grade. A common contract price is $\$ 1.50$ a foot for the first 100 feet and an increase of 50 cents a foot for each 50 feet thereafter. 


\section{CASING.}

The object in casing a well is to prevent the caving of the walls and to provide a straining surface to hold back loose material and admit water. In certain districts, notably in the vicinity of Florin, wells last a remarkably long time without casing, the stiff clays and hardpans and cemented sands of the alluvium standing without support even when a well is heavily pumped. For permanent wells, particularly on the west side, casing is usually necessary.

Oil well or screw casing is commonly used for deep wells made with drilling rigs. Screw casings have the advantage of strength to resist strains of all kinds and can usually be successfully removed. When made of wrought iron these casings are relatively resistant to rust. Double slip-joint or stovepipe casing is made of sheet iron riveted in tubes of two sizes. One size fits inside the other. In inserting the casing into a well the larger 2-foot length projects 1 foot beyond the smaller, and the joints are thus broken. The lengths are fastened together by denting with a sharp pick. This casing is used for both shallow and deep wells. Boring outfits ordinarily force the casing down with a lever; the drilling rigs are equipped with hydraulic jacks.

The advantages of stovepipe casing have been summed up by Slichter ${ }^{1}$ as follows, but many of the advantages which he mentions apply also to single sheet-iron casings:

1. The absence of screw joints liable to break and give out.

2. The flush outer surface of the casing without couplings to catch on bowlders or hang in clay.

3. The elastic character of the casing, permitting it to adjust itself in direction and otherwise to dangerous stresses, to obstacles, etc.

4. The absence of screen or perforation in any part of the casing when first put down, permitting the easy use of sand pump and the penetration of quicksand, etc., without loss of well.

5. The cheapness of large-size casings because made of riveted sheet metal.

6. The advantage of short sections, permitting use of hydraulic jacks in forcing casing into the ground.

7. The ability to perforate the casing at any level at pleasure is a decided advantage over other construction. Deep wells with much screen may thus be heavily drawn upon with little loss of suction head.

8. The character of the perforations made by the cutting knife are the best possible for the delivery of water and avoidance of clogging. The large side of the perforation is inward, so that the casing is not likely to clog with silt and débris.

9. The large size of casing possible in this system permits a well to be driven down in bowlder wash where a common well could not possibly be driven.

10. The uniform pressure exerted by the hydraulic jacks is a great advantage in safety and in convenience and speed over any system that relies upon the driving of the casing by a weight or ram.

1 Slichter, C. S., Field measurements of the rate of movement of underground waters: U. S. Geol. Survey Water-Supply Paper 140, p. 101, 1905.

$30644^{\circ}-$ wsP $375-16-3$ 
11. The cost of construction is kept at a minimum by the limited amount of labor required to man the rig as well as by the good rate of progress possible in what would be considered in many places impossible material to drive in and by the cheap form of casing.

The common type of casing for bored wells is made of galvanized sheet iron (soft steel) No. 20 to No. 14 gage, though any type of casing coming in short sections may be used. Sheot-iron casing is usually riveted into 2 or 3 foot lengths by the local tinsmith or the well borer. The upper part of each joint is spread a little and the lower part contracted so that the joints can be riveted together with a lap of 1 to 2 inches. To give greater strength a band or collar 3 to 6 inches wide is sometimes used at each joint. It is then called "collared casing." Where it is desirable to exclude the upper water, the joints are soldered as the casing is put down, to make it water-tight. Perforations are made with a cold chisel or a machine punch in the flat-that is, before the flat sheets of metal are shaped and riveted into cylinders. For house wells 4 to 8 inches in diameter such casings have been very satisfactory. When inserted in gravel at a depth of 25 to 100 feet, they frequently require no perforation to furnish water for a windmill or a small centrifugal pump. Some wells so equipped have been in continuous use for 30 to 40 years, but in general such wells should not be used over 15 to 20 years without recasing. The older wells are usually found to be full of tree roots, which may form such a mat as to clog the pipe. The presence of such vegetable matter, with its consequent decay, is undesirable in drinking water, as it is liable to give the water a bad odor or taste and to induce disease.

Single casings have not been so satisfactory in wells of larger diameters. In the weights ordinarily used sheet iron is not strong enough to stand the pressures which arise when obstacles are oncountered, especially if the casing has been weakened by perforation. The use of such casings in large wells intended for irrigation is too frequent and is responsible for many failures to obtain good irrigation supplies. Double slip-joint or heavy single iron, No. 12 to No. 8 gage, should be used. The disadvantages of single sheot-metal casings are as follows:

1. Single No. 20 to No. 14 sheet iron or soft steel is too weak to stand the stresses and pressures likely to be developed in inserting a casing, particularly when no drive shoe or starter is used.

2. The casing may buckle at any point, perhaps entailing the loss of the well, whereas a stovepipe casing will usually buckle at the top, where it is only a single thickness, thereby causing the loss of only the top joint.

3. The caving that often accompanies heavy pumping is likely to crush single casing and thus ruin the well. 
Success or failure in well making is dependent largely on the method of handling the water-bearing beds. Variations in the depth, thickness, and coarseness of the beds are so great and the possible combinations of these factors are so many that each well becomes a separate problem which must be solved on the ground. A description of the ordinary methods in use in the valley, illustrated by examples, together with a description of two screens not commonly used, is given in the following paragraphs. It is thought that this discussion will serve as a guide in meeting the conditions likely to be encountered in any particular well.

The common method of making a screen is to perforate the casing. It may be done before the casing is put down, but that practice is justified only when the depth and character of the water-bearing beds are known. In screw casings slots are cut with a chisel-two or three slots 2 feet long at each end of a 10 to 20 foot joint. Sheetiron casings are frequently perforated in the flat with a hatchet or cold chisel and when riveted into pipe the burrs are turned outside. Slots are also cut out by machine punches, and by this process a larger number of holes can be cut. Casings are greatly weakened when perforated and are therefore liable to be crushed when inserted.

Perforation of the casing after it is in place is a common practice. The size and position of the water-bearing beds are noted, and after the casing is inserted slots of a suitable size are cut by perforating machines. These machines are of various local patterns, but a common form consists of a heavy frame that nearly fills the casing and is hung from the derrick by*a rope or pipe line. A knife is pivoted in the frame and controlled by a second rope or pipe line. The machine is lowered to the desired place, and the slot is cut by pulling on the knife directly or by pulling the knife into position and sticking it through the casing by letting the full weight of the frame fall upon it. Skillful men working on wells that are not too deep can put from six to eight slots in a round, and one round every 6 inches in red steel slip-joint casing. The shape of the slot is governed by the shape of the knife, but very small slots are difficult to make, for a thin and consequently weak knife must be used. Slots three-eighths of an inch wide and 3 to 4 inches long are common and are suitable for the gravels ordinarily encountered.

Specially constructed well screens may be inserted in the waterbearing beds. These are of various types, but where it is necessary to obtain large water supplies from sand the wire-wrapped screen best meets conditions for the deeper wells. This screen is made by boring numerous holes in a length of pipe and then wrapping it with wire. The wire is spaced at a uniform distance, which is de- 
pendent on the size of the sand grains. Originally round wires were used, but these have been abandoned for a triangular wire which forms a slot narrow on the outside and larger within. Thus any material which passes the slot goes clear in and does not clog the screen. The spacing of the wires may be varied from one-thousandth to one-eighth of an inch. The size of the sand grains must, however, be determined by a test well, and screens of suitable sizes and lengths must be placed in the casing as it is put down. When only the sand at the bottom of a well is to be drawn on, a screen made to handle that sand may be inserted below the casing, as in oil wells. Wirewrapped screens are manufactured under several patents and vary in detail. The approximate price may be obtained from the accompanying table extracted from a manufacturer's catalogue:

Prices of wire-wrapped strainers.

\begin{tabular}{|c|c|c|}
\hline \multirow{2}{*}{$\begin{array}{l}\text { Diameter of } \\
\text { pipe. }\end{array}$} & \multicolumn{2}{|c|}{ Price per foot. } \\
\hline & $\begin{array}{c}\text { Galvanized } \\
\text { iron. }\end{array}$ & Brass. \\
\hline 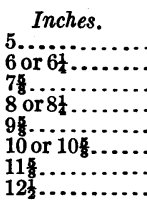 & $\begin{array}{r}\$ 2.75 \\
3.00 \\
3.65 \\
3.80 \\
4.00 \\
4.50 \\
5.00 \\
5.50\end{array}$ & $\begin{array}{l}\$ 3.60 \\
4.40 \\
4.50 \\
5.70 \\
6.00 \\
6.50 \\
7.00 \\
7.50\end{array}$ \\
\hline
\end{tabular}

In the ordinary methods of screening wells the best results are obtained when the water-bearing bed is a mixture of coarse and fine material. The screen should allow the finer material to pass but hold back the coarser to form a natural screen about the well. Such a gravel screen can be obtained artificially by introducing gravel or crushed rock or tile into the hole. ${ }^{1}$ A number of elaborate schemes have been devised for making an artificial gravel screen, ${ }^{2}$ but ordinary conditions may be met by relatively simple devices. A sheet-iron casing 16 to 26 inches in diameter may be sunk by ordinary well methods and a thoroughly perforated casing set inside of it. The perforations in this inner casing should be large and as numerous as possible without making the casing too weak. Selected gravel or crushed rock should then be poured between the casings, and the outer casing should be gradually lifted while the well is pumped. If the gravel settles, more gravel should be added at the top until a stable condition is reached, when the outside casing can be removed entirely. Wells of this type are successful in dealing

1 Hall, C. W., Meinzer, O. E., and Fuller, M. L., Geology and underground waters of southern Minnesota: U. S. Geol. Survey Water-Supply Paper 256, p. 87, 1911.

2 Maury, D. H., Open wells and turbine pumps: Eng. News, vol. 52, No. 7, pp. 138-140, Aug. $18,1904$. 
with sand near Enid, Okla. ${ }^{1}$ Their cheapness and effectiveness recommend them for use in places where the clays are so soft that they will cave if the sand under them is pumped out and not replaced by some other material and where no beds of gravel can be found.

EFFECTIVENESS OF WELL SCREENS IN SAND.

Where hardpan or clay beds will support a roof the best method of obtaining water from sands is to pump them out and draw water from the resulting open cavity, but in soft material or where the beds of sand are very thick screens must be provided. The results of the methods in common use are not very satisfactory. The difficulties are brought out in the account of L. F. Torry's well.

The plant of L. F. Torry, south of College City, was visited October 15, 1912. The well is 12 inches in diameter and more than 100 feet deep. It has a single galvanized-iron casing perforated in alternate 2-foot joints with 50 to 60 fine slits cut in the flat with a cold chisel. The following is a partial log of the well:

Partial log of L. F. Torry's well near College City, Cal.

\begin{tabular}{|c|c|c|}
\hline & Thickness. & Depth. \\
\hline 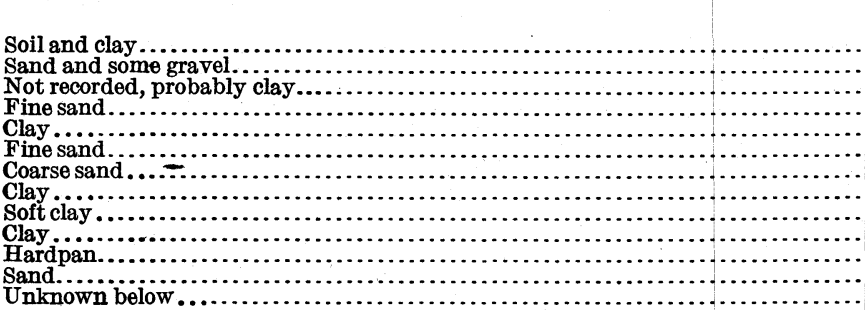 & $\begin{array}{c}\text { Feet. } \\
34 \\
2 \pm \\
20 \\
4 \\
2 \\
6 \\
2 \\
10 \\
12 \\
4 \\
2 \\
1-2\end{array}$ & $\begin{array}{c}\text { Feet. } \\
34 \\
36 \pm \\
56 \\
60 \\
62 \\
68 \\
70 \\
80 \\
92 \\
96 \\
98\end{array}$ \\
\hline
\end{tabular}

The equipment consists of a 3 -inch horizontal centrifugal Goulds pump, set 10 feet below the surface in a 6 by 6 foot planked pit 11 feet deep, and belted to an 8-horsepower Union gas engine. The depth to water, when the well was not being pumped, on October 15, 1912, was 18.3 feet from the surface of the ground. After the pump had been run 10 minutes the depth to water inside the casing was 35.7 feet, a drawdown of 17.4 feet. In boring the well the upper part of the hole was made more than 12 inches in diameter and thus there was a circular opening between the ground and the casing. The water level in this opening was 22.5 feet from the surface, and water was spraying through the perforations of the casing between this level and the level of the water inside the casing. These conditions are shown diagrammatically in figure 5. Under these conditions the

1 Schwennesen, A. T., Ground water for irrigation in the vicinity of Enid, Okla.: U. S. Geol. Survey Water-Supply Paper 345, p. 18, 1914. 
yield of the well could be increased by lowering the pump to 18 feet, the level of ground water, and thus increasing the head under which the waters enter the well. This would involve a larger lift for the pump and consequent greater cost of operation. By increasing the capacity of the strainer and admitting the water now being held out, more water could be obtained with the same lift. 9 With the present type of casing the number or size of the holes can not be increased materially without weakening the casing or admitting so much sand as to cause the well to cave. A common plan is to sink a new well of the same type and connect it with the plant by a suction main.

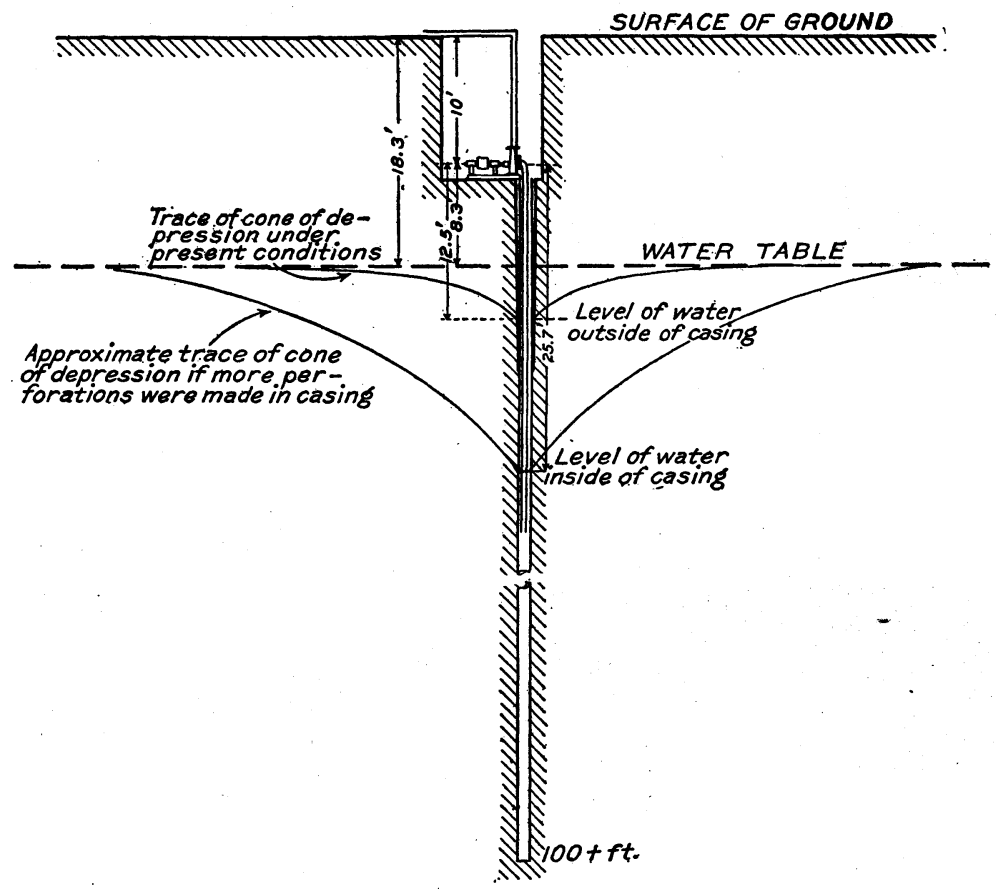

FIGURE 5.-Diagram of L. F. Torry's well near College City, Cal.

The problem may also be solved by using a more efficient strainer of the wire-wrapped type or a lining of gravel around the well, as described on pages 31-33. The first cost of wells constructed by these methods will be higher, but wells so constructed will have a longer life than wells with the ordinary single sheet-iron casing.

\section{EFFECTIVENESS OF WELL SCREENS IN GRAVEL.}

Screens made by perforations of the single or double sheet-iron casings are more effective in gravels or in sands carrying a sufficient number of pebbles to form a gravel screen around the well. The following descriptions of the Morris and St. Louis plants will bring 
out the characteristics of these screens in dealing with the thick gravel beds near Cache Creek:

The plant of Lindsay S. Morris, located 3 miles north of Yolo, is an example of good construction with single thickness casings. The plant consists of a 10-inch horizontal centrifugal Krogh pump belted to a 50-horsepower General Electric motor. The two wells are 12 inches in diameter, 50 feet apart, and 103 and 98 feet deep. Gravel similar to that which occurs in the present bed of Cache is found between depths of 58 and 114 feet, and water is drawn from this gravel only, the sand in the upper 58 feet being cased off. The casing is single galvanized sheet iron perforated in the flat by a machine punch with 333 holes $\frac{5}{16}$ by 1 inch to each 2 -foot joint. Each well has 50 feet of perforated casing in the gravel. The bottoms of the wells are closed with cast cement plugs, each having eight holes $1 \frac{1}{4}$ inches in diameter. The plugs were lowered into place by a bail and are designed to prevent the sucking in of gravels when pumping and yet admit sufficient water for the resulting current to prevent the accumulation of sand in the bottom of the well. The yield of the wells is estimated at 3,000 gallons a minute, or 1,500 gallons a minute each. In the season of 1913 the drawdown recorded by a vacuum gage was 27 inches of mercury, equivalent to 30.5 feet. Six-inch test wells were sunk 18 inches from each of the main wells, and on June 28, 1913, the depth to water in these wells was 24.5 feet, measured from the center of the pump, with the vacuum gage at 27 inches as before. In other words, the water outside of the casings stood 6 feet higher than was indicated by the gage for the inside. If a head of 2 feet is allowed for friction in the suction pipe, the difference in level between the inside and outside of the well was 4 feet. Further perforation of the casing to admit this water was impossible. Mr. Morris accordingly sank a 16-inch well with a similar casing between the other wells and 8 feet distant from a line connecting them. Water stood in this well, when only the other two were being pumped, 22.5 feet from the center of the.pump, or 6 feet higher than the level of the other wells. This well is expected to reduce the lift and therefore the cost of pumping and to slightly increase the amount of water.

The St. Louis plant of the Sacramento Valley Sugar Co., half a mile north of Yolo, will serve as an example of good well construction with stovepipe or double sheet-iron casing. The plant consists of 12 wells set 30 feet apart in a north-south line. A 15-inch horizontal centrifugal Byron Jackson pump in a 10 by 12 foot cement pit, 17 feet deep, belted to a 150-horsepower Westinghouse motor, is located at the center of the line of wells. The suction main lies in a series of tunnels connecting the pump pit with pits 4 feet square at each well. The suction pipes are $7 \frac{5}{8}$ inches in inside diameter and are 
connected to the suction pipe by a four-way union, which allows sand pumping of the wells without removal of the suction pipe. The diameter of the suction main increases from $7 \frac{5}{8}$ inches at the ends to 14 inches at the two sides of the pump. The plant discharges in two directions, east and west, to the banks of Cache Creek Slough, by riveted sheet-iron pipes. The east pipe is 18 ines in diameter and the west pipe 12 inches. The total lift is 42 feet, 15 feet discharge and 27 feet suction. The plant has a capacity estimated by C. E. Arnold, engineer for the company, at 7,000 gallons a minute.

The wells range from 98 to 107 feet in depth and tap two water-bearing gravels. The upper gravel is from 6 to 8 feet thick; below it is 20 to 22 feet of clay and at the bottom 55 to 60 feet of gravel. The casing is No. 14 gage red steel slip-joint or stovepipe casing and extends within 1 foot of the bottom of the lower gravel, the wells being open at the bottom. The perforations were made after the casing was inserted and, are triangular in shape, one-half inch wide at the top and tapering out in a length of 3 inches. The attempt was made to put eight holes in a round and one round every 6 inches for the depth of the gravel. Tally of the holes actually cut gave the following results:

Record of perforations of wells of the St. Louis plant, Sacramento Valley Sugar Co., north of Yolo, Cal.

\begin{tabular}{|c|c|c|c|c|c|c|c|}
\hline No. of well. & $\begin{array}{l}\text { Depth of } \\
\text { well. }\end{array}$ & $\begin{array}{l}\text { Thickness } \\
\text { of water- } \\
\text { bearing } \\
\text { gravel. }\end{array}$ & $\begin{array}{c}\text { Number of } \\
\text { perfora- } \\
\text { tions. }\end{array}$ & No. of well. & $\begin{array}{l}\text { Depth of } \\
\text { well. }\end{array}$ & $\begin{array}{l}\text { Thickness } \\
\text { of water- } \\
\text { bearing } \\
\text { gravel. }\end{array}$ & $\begin{array}{l}\text { Number of } \\
\text { perfora- } \\
\text { tions. }\end{array}$ \\
\hline 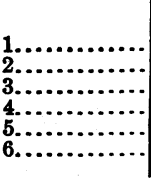 & $\begin{array}{r}\text { Feet. } \\
99 \\
98 \\
98 \\
98 \\
101 \\
99\end{array}$ & $\begin{array}{r}\text { Feet. } \\
69 \\
70 \\
71 \\
67 \\
71 \\
61\end{array}$ & $\begin{array}{r}896 \\
990 \\
941 \\
816 \\
a 636 \\
768\end{array}$ & $\begin{array}{r}7 \ldots \ldots \ldots \ldots \\
8 \ldots \ldots \ldots \\
9 \ldots \ldots \ldots \\
11 \ldots \ldots \ldots \ldots \\
12 \ldots \ldots \ldots \ldots \\
\end{array}$ & $\begin{array}{r}\text { Feet. } \\
99 \\
103 \\
104 \\
108 \\
109 \\
107\end{array}$ & $\begin{array}{r}\text { Feet. } \\
61 \\
60 \\
60 \\
66 \\
69 \\
62\end{array}$ & $\begin{array}{l}760 \\
832 \\
800 \\
860 \\
864 \\
862\end{array}$ \\
\hline
\end{tabular}

a About 200 more were put in but not tallied.

The perforating in these wells was done by competent workmen under good supervision, and the result may be taken as an example of the best strainer possible with casing of this type. The yield from each well is 583 gallons a minute. This compares unfavorably with the wells of the Morris plant, which yield about 1,500 gallons a minute each from gravels similar in size but in beds not quite so thick.

The wells of these plants, although they conform to the best practice characteristic of the valley, illustrate the faults common to many wells. Where a number of thin gravel beds occur the perforated stovepipe casing will be effective because its perforations will admit all the water which the beds can transmit. In thick beds of 
gravel, however, perforations can not be made in sufficient number to admit the water. This condition is illustrated by the difference in the yield per well of the Morris and St. Louis plants. Even the Morris wells do not have a great enough area exposed to the gravel. Sufficient perforations could be made in very heavy sheet-metal collared casing of No. 10 to No. 8 gage without reducing its strength and permanence below that of stovepipe casing. In shallow wells of large yield the velocities are so great that in order to prevent the rise of gravel in the well the bottom must be closed either by inserting the bottom of the casing in the underlying clay or, more effectively, by closing it with a plug, as in the Morris wells.

\section{PUMPING PROBLEMS.}

\section{GENERAL CONSIDERATIONS.}

The selection of proper pumping machinery for irrigation is a combined agricultural and engineering problem. Primarily that machinery which will lift the desired water most economically is the best, but machinery varies in the care and attention it requires and in its adaptability to overload and underload, and the most efficient form is different with various capacities and lifts. The conditions of agricultural practice are thus brought into the problem, and this is particularly the case in an area like the Sacramento Valley, where most of the plants are installed for single ranches by their owners.

\section{AMOUNTS OF WATER.}

The amount of water required for the irrigation of a tract of a given size varies with the climate, soil, and crops. The amount of water used for each unit of land irrigated is called the duty of water and is usually expressed in feet or inches of depth of water applied, or in acre-feet or acre-inches to the acre. Wide variations in the duty of water are common, ${ }^{1}$ but a safe figure for alfalfa on the "sediment" land is 30 acre-inches or 2.5 acre-feet to the acre. ${ }^{2}$ Tighter soils and orchard lands usually require less water. A duty of 2.5 acre-feet is equivalent to a continuous flow of 0.00839 cubic foot a second, or 3.76 gallons a minute for 5 months of 30 days each. For continuous operation of a pumping plant it is necessary to have a reservoir of sufficient size to hold the water pumped at night. The expense of a reservoir and the trouble of continuous operation are at present justified only when the yield of wells is small or there is a large reduction in the cost of power if taken continuously. The

1 Fortier, Samuel, Irrigation in the Sacramento Valley, Cal.: U. S. Dept. Agr. Office Exper. Sta. Bull. 207, 1909.

2 Beckett, S. H., Progress report of cooperative irrigation experiments at California University Farm, Davis, Cal., 1909-1912: U. s. Dept. Agr. Bull. 10, p. 7, Oct. 30, 1913. 
ordinary rancher does not expect to run his plant more than 20 days a month for 12 hours a day during the 5-month season, which would require a flow of 11.3 gallons a minute to furnish 2.5 acre-feet. Most small plants are probably in operation during an even smaller proportion of the time. At times of extreme heat the crop, particularly alfalfa, is likely to demand a quantity of water above normal, and it is therefore advantageous to have a margin of safety. The capacity should be large enough to provide water in such times of stress by pumping every day or possibly at night.

A small head is not economical in irrigating porous soils because water seeps away rapidly in such soils, and a head of water large enough to get over the ground must be used. Near Dixon, where the soil is a characteristic west-side loam, 3-inch centrifugal pumps are the smallest used and 5 or 6 inch pumps are considered the smallest practicable for irrigating alfalfa. In the Winters district, however, in the basin irrigation of orchards planted on similar land, about 400 gallons a minute, the yield of a 4 or 5 inch pump, is as large an amount as can be handled, though plants of this capacity may irrigate 100 acres. Near Corning, where the soil is tight and runs together when wet, small heads of water give the best results, and many 10-acre tracts of orchard and alfalfa are being irrigated with 2-inch pumps. Conditions somewhat similar to those at Corning prevail over the east-side plains.

In view of all these considerations a discharge of at least 12 gallons a minute to the acre should if possible be provided for alfalfa on ordinary loam soils in tracts of 40 to 200 acres, with larger capacities for smaller tracts and slightly smaller capacities for larger tracts.

In many places the problem is reversed and it is necessary to provide suitable equipment for wells of a known capacity and lift. After wells are sunk and tested, this is the problem to be solved, although in most localities in the Sacramento Valley it is possible to develop, through a series of wells, any desired capacity. The limiting factor is generally the cost, and in those localities where only small supplies are obtained by ordinary methods and with reasonable expenditure, such crops should be grown as require a minimum of water, and that in small heads.

\section{FORMS OF PUMPS.}

The centrifugal pump, because of its adaptability and ease of operation, has long been a favorite with irrigators. Modern practice in designing has increased the efficiency of these pumps, and except for extremely high lifts they are without question superior to displacement pumps for irrigation. The air lift is a device suitable for pumping from deep wells where power is furnished as a by-product 
of a larger plant and where constant expert attendance is available. The mechanical efficiency of the air lift is not high, and the method is not suitable for isolated plants that are run discontinuously. Because the air lift is very effective in cleaning the sand from a well and developing it to maximum capacity, it is useful in cleaning and testing new wells and has been so used by several large development companies.

A centrifugal pump consists of a set of vanes mounted on a shaft and inclosed in a pump case. When the shaft is rotated the water, which is admitted at the base of the vanes along the shaft, is given a radial motion and, as it is confined by the pump case, this motion is converted into pressure and lateral motion or discharge. Loss of the power applied to the shaft occurs through friction of water against the vanes and pump case, in eddies and swirls, and by the internal friction of the water. The different designs attempt to overcome these losses with a minimum cost.

A pump in which the water after leaving the vanes is directed by curved plates set in the pump case is known as a turbine. These pumps ordinarily develop the best efficiency and are capable of operating against high heads. They are used principally for hard, continuous service or as fire-pressure pumps.

The ordinary centrifugal pump is built without diffusion vanes and has a volute case which increases in size spirally toward the discharge and looks very much like a snail shell. Within the case revolve the vanes connected in a casting called the impeller. In a pump of the "open-runner" type the vanes are in direct contact with the case and water slippage is prevented only by matching of the vanes and case. A pump of the "closed-runner" type has plates cast or bolted to the vanes, and these plates are the only part of the impeller in contact with the pump case. Water is admitted through ports at the hub and does not come into contact with the case except at the top of the impeller. When there is much sand and grit in the water, as is common in wells, all exposed surfaces are liable to wear, which may considerably decrease the efficiency of the pump. Certain models are provided with renewable rings, which may be adjusted against the impeller and thus provide for wear.

A pump set on a horizontal shaft is called a horizontal centrifugal pump. Because of the difference in pressure between the suction and discharge of the pump the impeller tends to move toward the suction side. This is called end thrust and is taken care of by a friction bearing, by a water-balance device, or by admitting water on both sides of the impeller, as in double-suction pumps. The horizontal is the standard form of centrifugal pump and should be used wherever practicable. In pumping from wells or in other positions requiring a deep pit, a vertical centrifugal pump is sometimes 
used. This pump, with its vertical drive shaft, has the advantage that a short belt or direct drive can be used on the surface and power transmitted by the shaft. The pump will operate under water, and this is convenient where large fluctuations of the water table are likely to occur. The weight of the shaft and the end thrust must be supported by bearings, and friction losses from this cause decrease the efficiency of these installations. Top suction and a water-balance device afford some relief from end thrust. These pumps should not be used except to avoid long belts in places where the depth to water is more than 40 feet. Even for depths greater than 40 feet the directconnected centrifugal pump or deep-well turbine should be given consideration.

Where electric power is available centrifugal pumps are often connected directly to the motor. The horizontal pump is usually built on an extended cast-iron base and the shaft is connected by a flexible leather-link coupling to the shaft of a motor set on the same base. A considerable saving in power is effected by discarding a belt, but as motors have a fixed speed depending on their make, their horsepower, and the kind of current used, each unit, whether a vertical or a horizontal pump, must be separately designed to fit the conditions under which it is to work. The manufacturers on being furnished with complete information will design a direct-connected unit and guarantee a given discharge and efficiency.

In a form of centrifugal pump that has recently come into use the shafting is inclosed in the discharge pipe and the impeller in a series of small bowls, so that the whole apparatus will fit inside a well casing. As the impellers are small a number of bowls or stages are usually provided - one to each 20 or 30 feet of lift. Diffusion vanes guide the water from one impeller chamber to the next, so that this pump is of the turbine type. It is usually called the turbine centrifugal or deep-well centrifugal. The pump is supported at the ground and hangs free in the well. Power is applied at the surface by a quarter-turn belt to a pulley on the shaft or directly by a.vertical electric motor. These pumps are built in sizes from $9 \frac{5}{8}$ to 24 inches in diameter. With larger sizes a special circular steel pit to hold the pump is sunk by ordinary well methods around the well. The pit should be securely fastened to the top of the well casing. As the number of impellers can be easily increased, high heads can be handled, and the pump is proving very popular where water is deep. These pumps are also effective in obtaining maximum yields from poor wells. This is accomplished by setting the pump far below water level and pumping the water down more than is possible with the horizontal centrifugal pumps. This excessive lowering of the water level, however, causes a high lift and a heavy cost for power. Tur- 
bine centrifugal pumps take up but little room, are usually set so as not to require priming, are oiled from the surface, and require only a cheap pit which is covered and not dangerous to men and animals. However, a permanent derrick should be maintained over the pump, because for repairs or inspection the whole apparatus must be removed from the well.

\section{SIZES AND COST OF PUMPS.}

Centrifugal pumps are rated according to the size of the discharge openings in inches and are spoken of as 4-inch, 6-inch, etc., or No. 4, No. 6 , etc. These sizes or numbers give but a general idea of the capacity of the pumps, for the capacity varies with the head; with the speed at which the pump runs, and with the design of the impeller. The variation in capacity with speed and head makes it difficult to compare different manufacturers' designs. Normal capacity is usually figured for a 40-foot lift, and, of course, the maximum efficiency is obtained under the conditions for which the pump is designed. The lift may be varied either way 20 to 50 per cent, with a resulting loss in efficiency dependent in amount on the form of the impeller. The smaller sizes run at higher speeds than the large sizes and the same pumps must be run at a higher speed for greater heads. The large pump manufacturers maintain engineering departments whose services are available to customers, and consultation with them would avoid many of the common mistakes in installation.

The following table is taken from the catalogue of a well-known manufacturer and gives the capacities and characteristics of horizontal centrifugal pumps:

Size, capacity, and horsepower of single-stage belt-driven centrifugal pumps.

\begin{tabular}{|c|c|c|c|c|c|}
\hline \multirow{2}{*}{$\begin{array}{l}\text { No. of pump (size of discharge and suction open- } \\
\text { ings in inches). }\end{array}$} & \multicolumn{2}{|c|}{$\begin{array}{l}\text { Normal capacity } \\
\text { at } 40 \text { feet total } \\
\text { head. }\end{array}$} & \multirow{2}{*}{$\begin{array}{l}\text { Theoreti- } \\
\text { cal horse- } \\
\text { power for } \\
\text { each foot } \\
\text { of lift at } \\
\text { normal } \\
\text { capacity. }\end{array}$} & \multirow{2}{*}{$\begin{array}{l}\text { Recom- } \\
\text { mended } \\
\text { horse- } \\
\text { power for } \\
\text { each foot } \\
\text { of lift at } \\
\text { normal } \\
\text { capacity. }\end{array}$} & \multirow{2}{*}{ Price. } \\
\hline & $\begin{array}{c}\text { Gallons } \\
\text { a } \\
\text { minute. }\end{array}$ & $\begin{array}{l}\text { Second- } \\
\text { feet. }\end{array}$ & & & \\
\hline 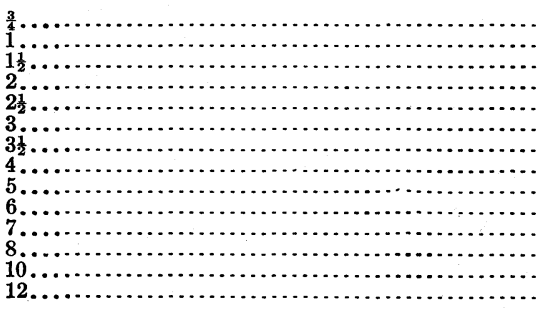 & $\begin{array}{r}10 \\
20 \\
50 \\
100 \\
150 \\
225 \\
300 \\
400 \\
700 \\
900 \\
1,200 \\
1,600 \\
3,000 \\
4,500\end{array}$ & $\begin{array}{r}0.02 \\
.04 \\
.1 \\
.2 \\
.3 \\
.5 \\
.6 \\
.9 \\
1.5 \\
2.0 \\
2.6 \\
3.5 \\
6.6 \\
10.0\end{array}$ & $\begin{array}{l}0.006 \\
.013 \\
.025 \\
.038 \\
.057 \\
.08 \\
.10 \\
.17 \\
.23 \\
.31 \\
.41 \\
.76 \\
1.13\end{array}$ & $\begin{array}{c}0.02 \\
.04 \\
.06 \\
.085 \\
.114 \\
.16 \\
.20 \\
.34 \\
.39 \\
.50 \\
.67 \\
1.17 \\
1.75\end{array}$ & $\begin{array}{r}\$ 25 \\
45 \\
55 \\
70 \\
85 \\
100 \\
115 \\
125 \\
150 \\
200 \\
250 \\
300 \\
400 \\
500\end{array}$ \\
\hline
\end{tabular}




\section{EFFICIENCY OF PUMPS.}

Manufacturers' tests of efficiency and capacity, as reported in the trade catalogues, frequently give results that can not be attained in actual practice. As a rule this is due not to any attempt by the manufacturers to deceive, but to the fact that the pumps are tested at the factory under favorable conditions that are not attained in most installations. The most important of these favorable conditions is a small suction lift. Throughout the valley suction lifts greater than those recommended by manufacturers are common, and it is a regular practice to increase the speed of the pump until the maximum suction lift, about 28 feet, results. This custom is justified during a dry season when crops demand water and the yield of the well is decreasing, but it should be practiced only in emergencies. It is more profitable in the long run to increase the supply of water by sinking more wells. It is ordinarily considered that with a centrifugal pump more than a 20 -foot suction lift should not be attempted. However, high suction lifts are difficult to avoid where there are large fluctuations in the water table if horizontal centrifugal pumps, which must be kept above water, are used. Thus, if the pump is installed just above the water level in March of a wet year it will be far above the water level in August of a dry year, and high suction lifts will be unavoidable unless suitable arrangements are made to lower the pump.

Adjustments to retain the efficiency and capacity of the plant with the changing lifts due to fluctuations of the water table can be made only after the extent of these fluctuations for the locality is known. If the pump is belted to the engine or motor its capacity can be adjusted to the lift by varying the pump speed. Two sets of pulleys, one for use in the spring, when the lift is low, and the other for use late in the summer, when the lift is high, should be provided. Directconnected outfits have a constant speed and the only means of adjusting them is to provide two impellers, one for the low lift and the other for the high lift. The saving in power that will result from such adjustments, which should be made only after consultation with the pump manufacturers, will amply repay the cost.

\section{INSTALLATION OF PUMPING PLANTS.}

After the completion of wells rough pits temporarily planked up are sufficient for testing, but when the size and type of pump are decided on a permanent pit of concrete should be built. The bottom of this pit should be at water level during the summer season, so that the pump may be set as close as possible to the water. The other dimensions of the pit depend on the size of the pump and 
whether it is belted or direct-connected. The pit should be carefully designed so as to afford working room around the pump and yet have no waste space. Dimension plates are published by all pump manufacturers, and from these the room required by the pump can be obtained. The pit may be either rectangular or circular, the circular form being slightly stronger but harder to construct. A 6-inch concrete wall without reinforcement is sufficiently strong for ordinary pits 10 to 20 feet deep. Reinforcement with woven wire or steel rods should be used in the shoulders of an inclined beltway, or the pressure of the soil will cause a failure of the wall at this point.

Bolts or timbers should be let into the side walls to facilitate the building of a stage on which to set the pump for pumping early in the spring when the pit is flooded. Another method is to make the concrete water-tight and seal the well around the suction pipe. This involves considerable expense and trouble and is not always successful. In installing direct-connected outfits means should always be provided for lifting the motor out of the pit during the winter.

When two or more wells are connected to a pump, a small pit should be constructed around each well. Except where sand occurs at water level, the cheapest method of connecting the several pits is

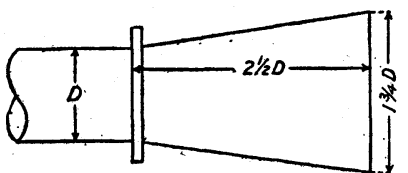

FIGURE 6.-Dimensions of enlargement of discharge and suction pipes. by tunneling from one to the other. The tunnel should be supported by timber or concrete.

Large pipes should be used throughout, and in order to avoid excessive losses from friction large-angle elbows should be used. Loss of head due to friction on entrance to the suction pipe and exit from the discharge pipe may be avoided by enlarging these openings. (See fig. 6.) The enlargement should not be abrupt but gradual. The following rule is given by Gregory: ${ }^{1}$ The diameter of the end should be $1 \frac{3}{4}$ times that of the pipe, and the enlargement should begin at a distance from the end $2 \frac{1}{2}$ times the diameter. The discharge pipe should lead to the bottom of a cement trough of . large size. The trough should lead to the ditch without any drop or waste head. Probably 50 per cent of the existing plants pump water from 1 foot to 6 feet higher than is necessary.

A suitable house should be built over the plant to protect it from the weather. This should be done the first season, for a few grains of sand or a little rust may do irreparable damage.

1 Gregory, W. B., The selection and installation of machinery for small pumping plants: U. S. Dept. Agr. Office Exper. Sta. Circ. 101, 1910, p. 19. 


\section{DISTRIBUTING SYSTEMS.}

Only a few of the plants in the valley have an adequate system of distribution. Crude earthen ditches are sufficient in tight soils, but in the loams of the west side and the river bottoms the loss by seepage in such ditches is great, and most of the water that is lost percolates downward and is of no value to the crop. The relatively tight soil of the Richfield tract, north of Corning, showed a loss of 17 per cent to the mile with a stream of 1,100 gallons a minute. In loam soils the loss often amounts to as much as 20 per cent in half a mile.

The use of cement pipe will prevent these losses and also bring about a saving of land and a reduction in the cost of irrigation. A comprehensive account of the manufacture and cost of cement pipe in southern California is given by Tait, ${ }^{1}$ from whose paper the following table of costs is taken:

\section{Cost of cement pipe at Pomona, Cal.}

\begin{tabular}{|c|r|r|}
\hline Size. & \multicolumn{1}{c|}{$\begin{array}{c}\text { cost per } \\
\text { foot. }\end{array}$} & $\begin{array}{r}\text { Cost per } \\
\text { foot laid. }\end{array}$ \\
\hline Inches. & & \\
$8 \ldots \ldots \ldots .$. & $\$ 0.121$ & $\$ 0.17$ \\
$10 \ldots \ldots \ldots .$. & .16 & .22 \\
$116 \ldots \ldots \ldots .$. & .22 & .32 \\
\hline
\end{tabular}

The cost of pipe in the Sacramento Valley, based on work done for the Mills Orchard Co., at Hamilton, is given by Mills ${ }^{2}$ as follows:

Cost of concrete pipe in Sacramento Valley.

\begin{tabular}{|c|c|c|c|}
\hline Size. & $\begin{array}{l}\text { Cost per } \\
\text { foot. }\end{array}$ & Size. & $\begin{array}{l}\text { Cost per } \\
\text { foot. }\end{array}$ \\
\hline $\begin{array}{l}\text { Inches. } \\
8 \ldots . . . \\
10 \ldots . . \\
12 \ldots . . . \\
16 \ldots . .\end{array}$ & $\begin{array}{r}\$ 0.28 \\
.35 \\
.43 \\
.56\end{array}$ & $\begin{array}{l}\text { Inches. } \\
18 \ldots \ldots \\
24 \ldots \ldots \\
30 \ldots \ldots \\
36 \ldots \ldots\end{array}$ & $\begin{array}{r}\$ 0.65 \\
.84 \\
1.10 \\
1.55\end{array}$ \\
\hline
\end{tabular}

These prices are for "wet-tamp" pipe, 1 part cement to 4 parts "gravel," the latter being the natural mixture found in streams, about 2 parts sand and 2 parts gravel. These estimates are based on cement at $\$ 2.50$ a barrel and gravel at 15 cents a cubic yard, both delivered at the pipe yard, and also allow for hauling the pipe from the pipe yard, an average distance of 1 mile. The cost of laying pipe is included, but not the cost of overflows, standpipes, valves, etc.

1 Tait, C. E., The use of underground water for irrigation at Pomona, Cal.: U. S. Dept. Agr. Office Exper. Sta. Bull. 236, pp. 56-60, 80-83, 1912.

2 Mills, E. C., Concrete pipe and overflow basins for distributing irrigation water: Eng. Record, vol. 67, No. 24, p. 652, June 7, 1913. 
It is believed that these costs will be reduced as the demand for pipe increases. Certainly it should be possible to manufacture pipe as cheaply in the Sacramento Valley as in southern California. It is reported that some contractors are ready at the present time to make a price of 35 cents a foot for 12-inch pipe.

John Borgman, a rancher near Nicolaus, says that 2,000 feet of 12inch pipe on his ranch cost less than 25 cents a foot. This pipe was laid continuously in a trench by the use of a form consisting of a 4-foot length of 12-inch galvanized pipe fitted with a handle in one end. The trench was carefully shaped, rounded on the bottom, and 15 inches wide. A layer of concrete $1 \frac{1}{2}$ inches thick was put in the bottom of the trench and the form was laid on top and covered with strips of burlap. Wires 14 inches long were bent over the form and thrust into the concrete on both sides. Concrete was then laid over the form for a depth of 2 inches. As soon as the next 4-foot bed of concrete was ready the form was slipped out and forward. The burlap strips allowed the form to slip out, and the wire reinforcement was sufficient to hold up the arch. Mr. Borgman and his son, after they became skillful, laid from 80 to 90 feet of pipe a day. The occasional leaks were not serious, but it was found that a mixture of 1 part cement, 2 parts sand, and 2 parts gravel was necessary to prevent seepage through the walls. Although pipe cast in molds is preferable for strength and adaptability and has the advantage that it can be easily inspected for defects, it is thought that the method devised by Mr. Borgman, with such simple adaptations as will occur to the irrigator, will enable men of small capital to equip their ranches with an effective pipe system.

\section{IRRIGATION WITH WELL WATER.}

Progress in irrigation has been rapid in the Sacramento Valley within the last few years, the principal development being in private irrigation plants using ground water. Most of the plants are situated in groups around the towns, partly because of economic reasons and partly because irrigation is infectious and the installation of one plant makes converts among the neighbors.

Statistics of irrigation were collected in the summer and fall of 1912 for the region west of Sacramento River between Willows and Rio Vista, and in the summer and fall of 1913 for the rest of the valley except Sacramento County. By correspondence and a short trip in 1913 the west-side material was brought up to date, so that the figures in the accompanying table represent conditions in 1913. Two short trips into Sacramento County were made by the writer in 1913 and 1914. In the winter of $1914 \mathrm{~J}$. W. Muller, of the Geological Survey, spent two months collecting statistics of pumping. The figures for $30644^{\circ}$-wsP $375-16-4$ 
the Sacramento area and the southern part of the Bear-American River area are the result of his work and cover the season of 1914.

An attempt was made to visit each pumping plant and to determine the area actually irrigated. Some difficulty was found in determining what should be considered a pumping plant for irrigation. In many places there are plants with 2 -inch pumps and 5-horsepower engines used to obtain water for stock and domestic purposes and for watering lawns and house gardens which were not considered as irrigation plants, but plants of the same size near Corning that are used for irrigating commercial orchards were listed as irrigation plants, though they are also used for domestic purposes. In the Sacramento area the combined suburban home and small farm is so common that practically all plants are listed. Irrigation was credited to a plant only where there was local evidence of irrigation at the time the plant was visited or where information that the plant was so used was deemed reliable. Proposed irrigation was rigidly excluded from the statistics.

The installed plants and acreage irrigated in 1913 (Sacramento County figures are for 1914) are presented in the following table, which is subject to minor revision. In this table the valley is divided into 19 areas in which pumping is concentrated in groups. These areas, the boundaries of which are arbitrary, are shown on the map of the valley (Pl. II).

Statistics of ground-water irrigation in the Sacramento Valley for 1913.

\begin{tabular}{|c|c|c|c|c|c|c|c|c|c|}
\hline $\begin{array}{c}\text { Area. } \\
\text { (See Pl. II.) }\end{array}$ & $\begin{array}{l}\text { Num- } \\
\text { ber of } \\
\text { plants. }\end{array}$ & $\begin{array}{l}\text { Num- } \\
\text { ber of } \\
\text { owners. }\end{array}$ & $\begin{array}{c}\text { Area } \\
\text { irri- } \\
\text { gated. }\end{array}$ & $\begin{array}{c}\text { Nomi- } \\
\text { nal } \\
\text { electric } \\
\text { power. }\end{array}$ & $\begin{array}{c}\text { Nomi- } \\
\text { nal } \\
\text { gaso- } \\
\text { line, } \\
\text { oil, and } \\
\text { steam } \\
\text { power. }\end{array}$ & $\begin{array}{c}\text { All } \\
\text { power. }\end{array}$ & $\begin{array}{l}\text { Aver- } \\
\text { age } \\
\text { power } \\
\text { per } \\
\text { plant. }\end{array}$ & $\begin{array}{c}\text { Aver- } \\
\text { age area } \\
\text { irri- } \\
\text { gated } \\
\text { for each } \\
\text { plant. }\end{array}$ & $\begin{array}{l}\text { A ver- } \\
\text { age area } \\
\text { irri- } \\
\text { gated } \\
\text { for each } \\
\text { horse- } \\
\text { power. }\end{array}$ \\
\hline 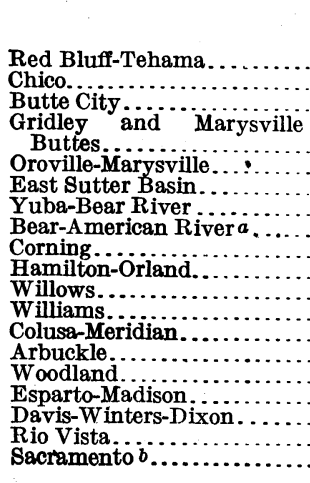 & $\begin{array}{r}25 \\
16 \\
7 \\
5 \\
23 \\
167 \\
22 \\
81 \\
84 \\
14 \\
67 \\
15 \\
14 \\
7 \\
37 \\
10 \\
128 \\
3 \\
939 \\
\end{array}$ & $\begin{array}{r}8 \\
15 \\
5 \\
5 \\
5 \\
23 \\
126 \\
19 \\
77 \\
66 \\
11 \\
46 \\
13 \\
14 \\
7 \\
26 \\
10 \\
111 \\
3 \\
837 \\
\end{array}$ & $\begin{array}{r}\text { Acres. } \\
1,387 \\
1,345 \\
470 \\
\\
115 \\
370 \\
4,144 \\
607 \\
1,450 \\
1,780 \\
1,405 \\
2,431 \\
280 \\
529 \\
70 \\
7,988 \\
148 \\
5,696 \\
19 \\
10,625 \\
\end{array}$ & \begin{tabular}{|r|}
$\begin{array}{r}\text { Horse- } \\
\text { power. }\end{array}$ \\
297 \\
375 \\
45 \\
\\
105 \\
150 \\
1,106 \\
175 \\
129 \\
483 \\
160 \\
575 \\
100 \\
165 \\
\hdashline 1,812 \\
25 \\
1,302 \\
20 \\
3,661 \\
\end{tabular} & $\begin{array}{r}\text { Horse- } \\
\text { power. } \\
30 \\
34 \\
30 \\
15 \\
15 \\
39 \\
195 \\
52 \\
530 \\
73 \\
45 \\
122 \\
63 \\
139 \\
28 \\
140 \\
60 \\
529 \\
4 \\
2,329 \\
\end{array}$ & \begin{tabular}{|r|} 
Horse- \\
power. \\
327 \\
409 \\
75 \\
\\
120 \\
189 \\
1,301 \\
227 \\
659 \\
556 \\
205 \\
697 \\
163 \\
304 \\
28 \\
1,952 \\
85 \\
1,831 \\
24 \\
5,990 \\
\end{tabular} & $\begin{array}{r}\text { Horse- } \\
\text { power. } \\
13.0 \\
25.5 \\
10.6 \\
\\
24.0 \\
8.2 \\
7.7 \\
10.3 \\
8.1 \\
6.6 \\
14.6 \\
10.4 \\
10.8 \\
21.7 \\
4.0 \\
52.7 \\
8.5 \\
14.3 \\
8.0 \\
6.3 \\
\end{array}$ & $\begin{array}{r}\text { Acres. } \\
55.4 \\
84.0 \\
68.2 \\
23.0 \\
16.1 \\
24.8 \\
27.5 \\
17.9 \\
20.2 \\
10.3 \\
36.2 \\
18.6 \\
37.7 \\
10.0 \\
21.8 \\
14.8 \\
44.5 \\
6.3 \\
11.3\end{array}$ & $\begin{array}{r}\text { Acres. } \\
4.2 \\
3.3 \\
6.2 \\
.9 \\
1.9 \\
3.2 \\
2.6 \\
2.2 \\
3.2 \\
6.8 \\
3.5 \\
1.7 \\
1.7 \\
2.5 \\
4.1 \\
1.7 \\
3.1 \\
.8 \\
1.7\end{array}$ \\
\hline & & 1,422 & 40,859 & 10,685 & 4,457 & 15,142 & 9.1 & 24.5 & 2.7 \\
\hline
\end{tabular}


Of the total horsepower used 70 per cent is electric; the rest is developed by internal-combustion engines and by a few steam engines in old plants. High-tension electric-power lines of several different companies cross the valley to the bay cities from water-power plants located in the Sierra Nevada. Local power lines at lower voltage run out through the country from numerous transformer stations on the main lines. Those areas in which the power produced by gasoline, oil, and steam engines equals or exceeds the electric power have scattered plants, many of which are far from power lines. The large use of gasoline power in the Davis-Winters-Dixon area is due partly to the fact that a number of plants were installed before electric power was available and partly to a belief that gasoline plants are cheaper.

The average horsepower to a plant is 9.1, and the average area irrigated 24.5 acres, or 2.7 acres for each horsepower used. Wide variations in the size of the plants and the acreage per horsepower exist in the several districts. They are not due primarily to differences in lift, for the lifts do not vary much from one district to the other, but to differences in soil and crops and in the size of farm units. The Butte City and Hamilton-Orland areas have a large acreage per horsepower because of the economical irrigation of young orchards by large companies. The East Sutter Basin area is also predominantly an orchard district, but the plants supply small tracts because the land is in small blocks and each owner irrigates only his own land. Relatively large heads of water are, however, required in this area to cover the ground, and therefore small plants are not practicable. Economy could be effected by cooperation between neighbors. The use of one plant by several ranchers would reduce the interest and depreciation charges, which form so large a part of the cost of pumped water.

The average irrigation in all areas is brought down by the inclusion of plants recently installed, which irrigated only small tracts in the following year. An effort should be made when a new plant is installed to complete the grading and checking of the land so that the plants can be brought into full use without undue loss of time.

The machinery installed in the pumping plants of the valley is capable of a certain amount of work, which can be estimated for assumed conditions and compared to the actual results in acreage irrigated. While no large series of tests have been made, it may be assumed that the plants have an over-all efficiency of 40 per centthat is, that 40 per cent of the nominal horsepower of the motors and engines is actually effective in lifting water. This figure is assumed on the ground that the large number of direct-connected electric units of high efficiency will balance the plants of low efficiency. The 
average lift may be taken at 40 feet, which is perhaps a high rather than a low figure.

The average of 9 horsepower to the plant, as given in the table (p. 46), with a plant efficiency of 40 per cent and a lift of 40 feet, will deliver 358 gallons a minute. On page 38 it is stated that the time a plant ordinarily runs is 12 hours a day and 20 days a month for 5 months. With this pumping time 11.3 gallons a minute is necessary to furnish 2.5 acre-feet an acre for the season, which is nearly the right figure for alfalfa, though much too high for orchards. This pumping time is based on five irrigations of 6 inches each, which is common on alfalfa. However, the irrigations are not always evenly divided, the third and fourth irrigations often being much heavier than the others. A discharge of 11.3 gallons a minute to the acre will allow $7 \frac{1}{2}$ inches to be applied in 28 days' pumping, 12 hours a day. Heavier irrigations are seldom necessary but can be provided by night pumping. The time required for one irrigation can also be reduced by operating the plant for a longer time each day. The necessity which may arise at certain times for large applications of water and for getting a field irrigated quickly in order to keep the crop growing justifies large installations. The intelligent irrigator will, however, attempt to reduce the peak load on his irrigation plant by adjustments of his system of agriculture in order to use as small a plant as is possible.

At 11.3 gallons a minute to the acre a discharge of 358 gallons a minute (from a 9-horsepower plant) for 12 hours a day will irrigate 31.6 acres with 2.5 feet of water for the season. By increasing the pumping time to 16 hours a day for the 100-day season, the same discharge will irrigate 42.3 acres with the same amount of water. With this increased pumping time and a reduction in the amount of water applied from 2.5 feet to 2 feet the same plant will supply 52.8 acres.

While 24.5 acres, the average acreage to the plant derived from the statistics (p. 46), is a rough figure and includes many different kinds of plants pumping on different kinds of crops, it is so near the figure, 31.6 acres, obtained by assuming the conditions stated above in full that it indicates either that the valley plants are fairly efficient and well used or that the assumptions do not represent average conditions as to lift and duty of water. It will be seen from the following analysis that the assumptions are good for an average plant irrigating field crops. Many plants have low lifts or irrigate orchards and do not comply with the assumptions. In irrigating porous soils a discharge as small as 358 gallons a minute is easily lost by seepage and will not irrigate as much land as the figures call for. The large increase in acreage with increased running time is exceedingly significant. Analysis shows that the average area irrigated by each plant can be 
raised when through a keener realization of the saving effected each owner obtains for his plant the best mechanical efficiency and fullest economical use.

It is believed that the assumption for lift of 40 feet is about the average for the valley, but that, although 2.5 feet is the proper amount of water to use on alfalfa and is used in good practice in Dixon and other places, much less water is usually applied in good practice to orchards. The average use of water is therefore less than 2.5 feet. If the assumption of 2.5 feet for duty of water is too high, then it is evident that the acreage irrigated is too small and should be increased.

An increase of pumping time by 4 hours a day will increase the average acreage for each plant to 42.3 acres, and at many plants this increase, with the consequent reduction in cost to the acre for irrigation, can easily be made. The assumption of a 40 per cent over-all efficiency of the plants may be too high, but this is a minimum standard to which irrigators should try to bring the mechanical efficiency of their plants. It is usually exceeded in direct-connected electric units. Improvements in efficiency of many plants can be made by slight, inexpensive changes, such as enlargement of discharge pipes, elimination of unnecessary elbows, reduction of discharge height to that just necessary to put water in the ditch, and other devices which are illustrated by the numerous plants of high efficiency to be found in any pumping district. It is obvious that the irrigators have an opportunity to make much greater use of their present aggregate investment in wells and pumping machinery. 
